\title{
Petrography and origin of dedolomites of the Ordovician Majiagou formation in the southeastern Ordos Basin, China: implications for reservoir quality
}

\author{
Lihong Liu ${ }^{1,2} \cdot$ Chunlian Wang $^{3}$ (D) Keke Huang ${ }^{4} \cdot$ Zhili Du$^{1}$
}

Accepted: 5 October 2021 / Published online: 17 October 2021

(c) The Author(s) 2021

\begin{abstract}
Dedolomites, the replacement of dolomite by calcite, are widely distributed in the Ordovician Majiagou Formation of the southeastern Ordos Basin, China, which critically affects reservoir quality throughout the region. Two types of dedolomites were recognized in the upper $100 \mathrm{~m}$ of the Majiagou Formation, namely brecciated dedolomite and crystalline dedolomite. The petrographic and geochemical data reveal that the investigated dedolomites are often associated with clay minerals and dissolution-collapse breccia, indicating their close relationship with erosional unconformities. The relative negative $\delta^{18} \mathrm{O}$ and $\delta^{13} \mathrm{C}$ values and relative high $\mathrm{Fe}, \mathrm{Mn}$ contents of dedolomite with respect to corresponding dolomite are interpreted as being result from meteoric phreatic water involvement. The dedolomitization process related to subaerial exposure is conventionally interpreted to be formed by dolomite dissolution and calcite precipitation. The rhombic shape crystals in the brecciated dedolomite was formed by an $\mathrm{Mg}^{2+}$-loss process under evaporite solution conditions, which retain the rhombic shape of the dolomite. The crystalline dedolomites, however, were formed by dissolution/precipitation and recrystallization process to form medium to coarse calcite mosaic with very low intercrystalline porosity. The resulting fabrics are mainly controlled by the paleo-topography. The precursor dolomite of the crystalline dedolomite is primarily recrystallized mudstone, which is more soluble and favorable for calcite precipitation. The crystalline dedolomite mostly occurs in the low paleotopographic locations, where the karst-saturated water with respect to $\mathrm{CaCO}_{3}$ is more concentrated, occluding the remaining porosity when excess calcium is supplied. It's, therefore, recommended to implement drilling in tectonic highland and avoid low paleotopographic locations.
\end{abstract}

Keywords Dedolomitization $\cdot$ Majiagou formation $\cdot$ Diagenetic stages $\cdot$ Reservoir quality $\cdot$ Ordos Basin

Chunlian Wang

wangchunlian312@163.com

1 Oil and Gas Survey, China Geological Survey, Beijing 100083, China

2 Oil and Gas Research Center, School of Earth and Space Sciences, Peking University, Beijing 100871, China

3 MNR Key Laboratory of Metallogeny and Mineral Assessment, Institute of Mineral Resources, Chinese Academy of Geological Sciences, Beijing 100037, China

4 State Key Laboratory of Oil and Gas Reservoir Geology and Exploitation, Chengdu University of Technology, Chengdu 610059, China

\section{Introduction}

Dedolomitization is a process by which dolomite is replaced by calcite in the presence of a calcium-rich solution, which is often associated with evaporite minerals dissolution. The product of dedolomitization is referred to as dedolomite (Von Morlot 1847; Shearman et al. 1961; Evamy 1967; Flügel 2010). Dolomitization is relatively well documented, whereas little attention has been paid to dedolomitization. Dedolomitization occurs under a wide range of diagenetic conditions, such as during burial-diagenesis (Stoessell et al. 1987; Schoenherr et al. 2018), related to contact metamorphism (Faust 1949; Wood and Armstrong 1975), and associated with hydrothermal activity (Ronchi et al. 2004; Huang et al. 2013; Lyu et al. 2013). However, most of the reported dedolomite occurrences are indicative of near-surface conditions, and associated with the effects of meteoric water along 
unconformities (Kenny 1992; Nader et al. 2008; Fu et al. 2008; Reuning et al. 2009).

With respect to dedolomitization effects on the reservoir quality, a simulation performed by Escorcia et al. (2013) proposed that a porosity reduction is owing to calcitization. However, only when the extent of dolomite and evaporite dissolution exceeds that of calcite precipitated, the overall porosity can be increased (Canaveras et al. 1996; Ayora et al. 1998; Nader et al. 2008). In most cases, dolomite dissolution and calcite precipitation occur in different solutions at different time, owing to excess of calcium supplied to the system that leads to calcite cementation. Calcite crystals often mosaic contact tightly that reduces reservoir porosity (Fu et al. 2008). However, the porosity reduction by dedolomitization in aforementioned case study is more likely to be caused by calcite cementation. Therefore, the question of whether the reservoir quality is enhanced by dedolomitization or not remains controversial.

Dedolomitization can be controlled by several factors, such as the $\mathrm{Ca}^{2+} / \mathrm{Mg}^{2+}$ ratio in the diagenetic fluid (Khalaf and Abdal 1993), dolomite stoichiometry (Nader et al. 2008), $\mathrm{CO}_{2}$ partial pressure (De Groot 1967; Clark 1980; Hallenberger et al. 2018), temperature and salinity (Hardie
1967; Hallenberger et al. 2018) and the degree of fracture development (Al-Hashimi and Hemingway 1973; Budai et al. 1984; Zeeh et al. 2000; Reuning et al. 2009). The major factors that control dedolomitization in the Majiagou Formation are discussed in this study to provide further insight into the dedolomitization process.

Moreover, this study aims to provide new data on dedolomite fabrics, mechanisms, and effect of dedolomitization on reservoir quality of the Ordovician Majiagou Formation of the Ordos Basin in China as a case study, and to discuss its possible origin by means of detailed thin section investigation, scanning electron microscope (SEM), energy dispersive spectroscopy (EDS) analysis and stable isotope measurements.

\section{Geological setting}

The Ordos Basin, the second largest basin in China with an area of $2.5 \times 10^{5} \mathrm{~km}^{2}$, is a large scale intra cratonic basin (Fig. 1) (Yang et al. 2011). The basin was uplifted during the Caledonian orogeny in the early Paleozoic (He 2003) and subject to deep erosion for more than $140 \mathrm{My}$, resulting in
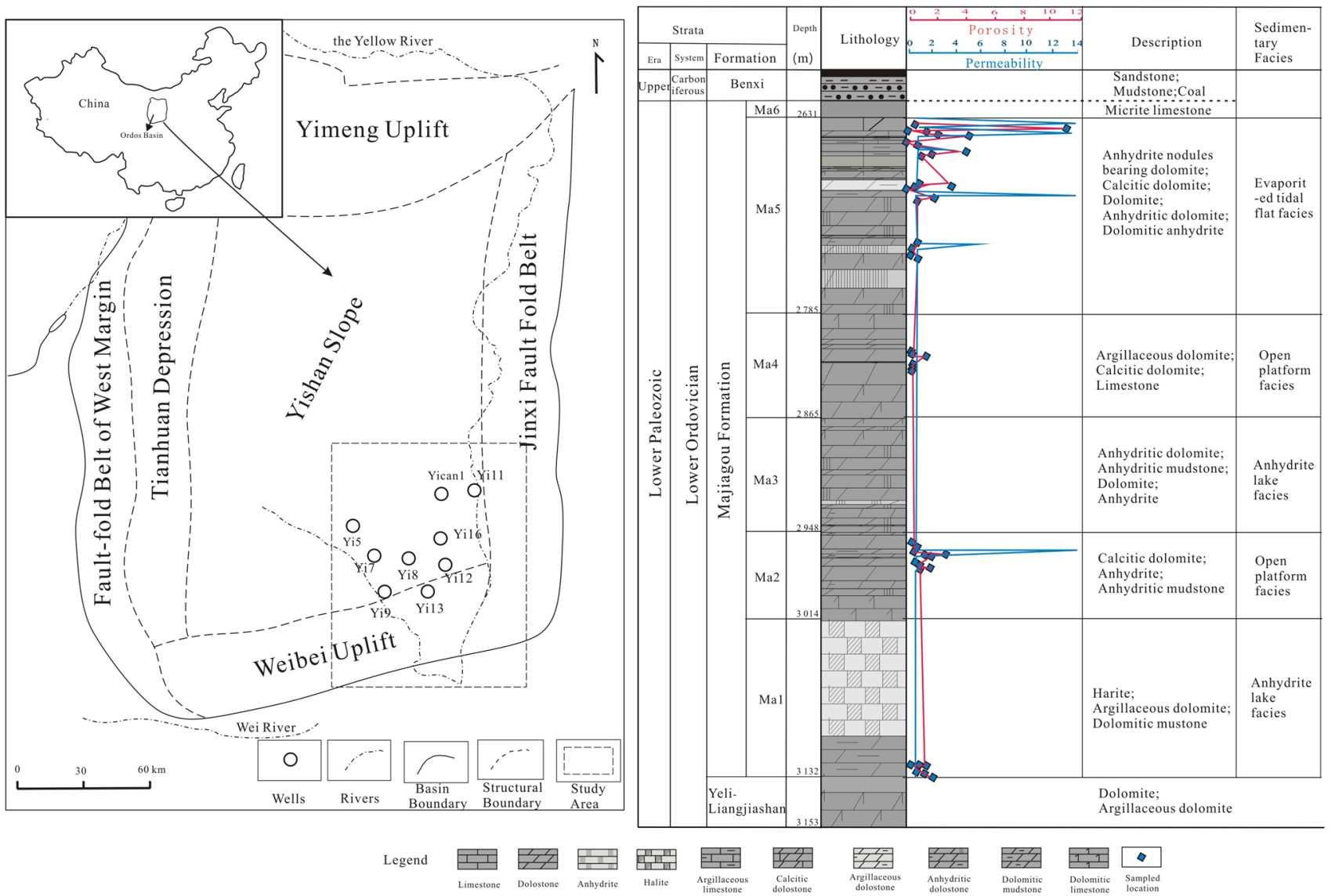

Fig. 1 Simplified structural map of the Ordos Basin showing the study area (He 2003) and the lithocolumn of main sampled Yican1 well 
the missing of Silurian, Devonian and Early Carboniferous rock units (Yang et al. 2005) forming a significant regional unconformity above the Ordovician Majiagou Formation. The carbonate succession of the Ordovician Majiagou Formation has a thickness of $>500 \mathrm{~m}$ that is overlain by continental sediments of the Carboniferous Benxi Formation (Fig. 1). According to its structural framework, the Ordos basin can be subdivided into six tectonic units, these are the Jinxi flexible fold belt, Weibei uplift, a western margin thrust belt, Yishan slope, Tianhuan depression and Yimeng uplift (Feng et al. 1999; Fu et al. 2001; Wei et al. 2019). The study area is located in the southeastern Ordos Basin across the Yishan slope and Weibei uplift (Fig. 1).

The Ordovician Majiagou Formation can be subdivided into successive six members $\left(\mathrm{Ma}_{1} \sim \mathrm{Ma}_{6}\right.$ from base to top). Owing to periodic sea level change, a set of transgression-regressive cycles are represented in the Majiagou Formation, in which the $\mathrm{Ma}_{1}, \mathrm{Ma}_{3}$ and $\mathrm{Ma}_{5}$ members are mainly composed of dolomite and anhydrite in evaporitic tidal flat facies and marine anhydrite lake facies, whereas the $\mathrm{Ma}_{2}, \mathrm{Ma}_{4}$ and $\mathrm{Ma}_{6}$ members are dominated by limestone and dolomite representing open platform facies (Fig. 1) (Li et al. 2008; Yang et al. 2011). The $\mathrm{Ma}_{6}$ member consisting mainly of limestone is eroded in most regions and occurs in the southern part of the basin with a thickness ranging from 10 to $20 \mathrm{~m}$ (Bao et al. 2004). The $\mathrm{Ma}_{1}$ to $\mathrm{Ma}_{5}$ members are developed across the basin and can be laterally traced for several kilometers. Although the limestone of the $\mathrm{Ma}_{6}$ is developed in southeast of the Ordos basin overlying the $\mathrm{Ma}_{5}$ dolomite, due to its vicinity to the central paleouplift in Caledonian period, bedding karstification may occur in the $\mathrm{Ma}_{5}$ in slope region (Tian et al. 2017). Dolomite of the $\mathrm{Ma}_{5}$ was therefore subject to meteoric diagenesis and karstification in the study area. Up to 10 sub-members $\left(\mathrm{Ma}_{5}{ }^{1}\right.$,
$\mathrm{Ma}_{5}{ }^{2} \ldots \mathrm{Ma}_{5}{ }^{10}$ from top to bottom) have been identified in the $\mathrm{Ma}_{5}$ member with cyclic carbonate-evaporite intervals related to the short term sea-level variations (Fig. 1) (Bao et al. 2004). The $\mathrm{Ma}_{5}{ }^{1}$ to $\mathrm{Ma}_{5}{ }^{4}$ sub-members are mainly composed of microcrystalline dolostone, anhydrite, karst breccia and dolostone with anhydrite nodules. Dolostone with anhydrite nodules is interpreted to be formed by penecontemporaneous dolomitization mode of sabkha evaporative tidal flat (Bao et al. 2017). Because of the dissolution of anhydrite nodules in meteoric water, a favorable reservoir is developed in the upper four sub-members of the $\mathrm{Ma}_{5}$, which becomes major gas producing strata (Tian et al. 2017). For instance, the Yican 1 well, drilled in karst monadnock in 2014, produced $3.5 \times 10^{4} \mathrm{~m}^{3}$ gas daily in $\mathrm{Ma}_{5}{ }^{1}$ and $\mathrm{Ma}_{5}{ }^{4}$ submembers where the anhydrite moldic pores and fractures are developed. Whereas Yi 5, Yi 9, Yi 13, Yi 16 wells located in karst groove commonly have low production of oil and gas.

\section{Sampling and methods}

More than 240 core samples of the Ordovician Majiagou Formation were taken from 9 wells in the southeast of the Ordos basin and were examined by optical microscope (Fig. 1). More than $100 \mathrm{~m}$ cores are obtained from the Yican 1 well (Table 1). A total of 72 samples were analyzed for oxygen and carbon isotopes and trace element geochemistry. Prepared thin sections were stained with Alizarin Red S to differentiate between calcite and dolomite following Lindholm and Finkelman (1972). Core-plug porosity and permeability were determined from 72 samples using conventional 3020-062 helium porosimetry and Klinkenberg-corrected GDS-90F gas permeametry according to GB/T29172-2012 Core Analysis Method.
Table 1 Coring table of Yican 1 well

\begin{tabular}{lllccc}
\hline Core barrel & Formation & Cores $(\mathrm{m})$ & $\begin{array}{l}\text { Drilling } \\
\text { interval }(\mathrm{m})\end{array}$ & Core interval $(\mathrm{m})$ & Core recovery (\%) \\
\hline 5 & & & & \\
6 & $\mathrm{Ma}_{5}{ }^{1}$ & $2632.98 \sim 2636.68$ & 3.70 & 3.66 & 98.92 \\
7 & $\mathrm{Ma}_{5}{ }^{2}$ & $2636.68 \sim 2652.07$ & 15.39 & 14.70 & 95.52 \\
8 & $\mathrm{Ma}_{5}{ }^{3}$ & $2652.07 \sim 2658.07$ & 6.00 & 5.50 & 91.67 \\
9 & $\mathrm{Ma}_{5}{ }^{4}$ & $2677.02 \sim 2683.50$ & 6.48 & 5.45 & 84.10 \\
10 & $\mathrm{Ma}_{5}{ }^{4}$ & $2683.50 \sim 2692.70$ & 9.20 & 6.05 & 65.76 \\
11 & $\mathrm{Ma}_{5}{ }^{6}$ & $2723.82 \sim 2733.03$ & 9.21 & 9.21 & 100.00 \\
12 & $\mathrm{Ma}_{4}$ & $2806.74 \sim 2814.76$ & 8.02 & 2.70 & 33.67 \\
13 & $\mathrm{Ma}_{4}$ & $2814.76 \sim 2823.96$ & 9.20 & 9.18 & 99.78 \\
14 & $\mathrm{Ma}_{2}, \mathrm{Ma}_{3}$ & $2943.00 \sim 2952.70$ & 9.70 & 9.66 & 99.59 \\
15 & $\mathrm{Ma}_{2}, \mathrm{Ma}_{3}$ & $2952.70 \sim 2962.40$ & 9.70 & 9.66 & 100.00 \\
16 & $\mathrm{Ma}_{2}$ & $2962.40 \sim 2972.10$ & 9.70 & 9.70 & 100.00 \\
17 & $\mathrm{Ma}_{1}$ & $3120.00 \sim 3129.00$ & 9.00 & 9.00 & 99.78 \\
Total & $\mathrm{Sanshanzi}$ & $3190.80 \sim 3200.00$ & 9.20 & 9.18 & \\
\hline
\end{tabular}


Powder samples ( 30-50 mg per single sample) of dolostone, brecciated dedolomite and crystalline dedolomite were extracted for carbon and oxygen isotope measurements. Samples are microdrilled with a handheld dental drill. The powdered samples were heated to remove organic materials and then reacted with anhydrous phosphoric acid, under vacuum condition, to release $\mathrm{CO}_{2}$ at $25^{\circ} \mathrm{C}$ for $24 \mathrm{~h}$. The $\mathrm{CO}_{2}$ was then analyzed for $\delta^{13} \mathrm{C}$ and $\delta^{18} \mathrm{O}$ value on a Finnigan MAT251 mass spectrometer. All $\delta^{13} \mathrm{C}$ and $\delta^{18} \mathrm{O}$ values were reported in \%o units relative to the Vienna Pee Dee Belemnite (VPDB) standard.

Ultra-fabrics were studied using a Melin type Scanning Electron Microscope (SEM) (Carl Zeiss AG) operated at $15-20 \mathrm{kV}$ with a $10 \mathrm{nA}$ beam current and working distance of $10 \mathrm{~mm}$. The elemental concentrations and spatial variation of micron-sized spots were obtained by EnergyDispersive Spectrometry (EDS) at the China University of Petroleum (College of Geosciences), which could generate high-resolution, high-magnification images of carbonate textures.

\section{Results}

\section{Petrography}

The Ordovician Majiagou Formation in the study area ( $\mathrm{Ma}_{1}-\mathrm{Ma}_{6}$ members) are mainly composed of five lithofacies types including dolostone, calcitic dolostone, crystalline limestone, anhydrite dolostone and dolomitic anhydrite.

\section{Dolostone lithofacies}

Dolostone is the dominant lithology in the Majiagou Formation. Two types of dolostone were recognized in the Majiagou Formation, including dolostone with anhydrite nodules and dolostone without anhydrite nodules. The anhydrite nodule-bearing dolostone is restricted to the $\mathrm{Ma}_{5}{ }^{1}$ submember with a thickness less than $10 \mathrm{~m}$. These rocks are mainly composed of dark gray dolomicrite with the size of $10 \sim 30$ um and the nodules accounting for 5\%-10\% of the core sample with size of 1-2 mm (Fig. 2a-c). Most anhydrite nodules are dissolved (Fig. 2a, b), where pores are filled with fine crystalline dolomite, medium-coarse calcite, authigenic quartz and pyrite (Fig. 2c).

The dolostone without anhydrite nodules is mainly distributed below the $\mathrm{Ma}_{5}{ }^{4}$ sub-member. The dolostone is composed mainly of dolomicrites. Some dolomicrites are argillaceous sediments showing banded structure. The crystals of dolomicrites are subhedral or anhedral, which are tightly interlocked and mosaic contacted.

\section{Calcitic dolostone lithofacies (Brecciated dedolomite)}

The brecciated dedolomite lithofacies is mainly composed of dark gray matrix and light gray clasts with size of $0.1 \sim 1 \mathrm{~cm}$ (Fig. 2d-f). The rock has been cracked with cmscale pockets of clays filled in the fractures (Fig. 2d). Some rocks exhibit brownish and reddish color in hand specimen (Fig. 2d). Detailed microscopic investigation reveals that the dark gray matrix is mainly composed of dolomicrite (Fig. $2 \mathrm{~g}-\mathrm{i}$ ). The light gray clasts mainly contain very fine to medium subhedral to euhedral calcitized dolomite crystals with sizes ranging from 10 to $200 \mathrm{~mm}$ (Fig. $2 \mathrm{~g}-\mathrm{i}$ ) and fine crystalline dolomite matrix. The calcitized dolomite crystals, which have been stained red by Alizarin Red S, are scattered in the micritic dolostone matrix or form crystal aggregates as the clasts of breccia (Fig. 2g). This type of calcitized dolomite crystals are identified as dedolomites. The fractures and veins are well developed, which cut both the matrix and clasts (Fig. 2h). The studied brecciated dedolomite mainly occurs in the uppermost $100 \mathrm{~m}$ of the $\mathrm{Ma}_{5}$, corresponding to the $\mathrm{Ma}_{5}{ }^{1}-\mathrm{Ma}_{5}{ }^{4}$ sub-members below the paleo-karstic surface located at the top of the Majiagou Formation in the Yican 1 well (Fig. 1).

The SEM analyses show that the dark gray crystals in the large rhombic crystals (Fig. 3a, point 27) exhibit dolomite peak shapes in the EDS spectrum (Fig. 3b), whereas the light gray parts of the rhomb show calcite peak shapes (Fig. 3c, $\mathrm{d}$, point 28). Four types of microfabrics are recognized in the dedolomite crystals: (1) cloudy cores of precursor dolomite rhombs are often preferentially replaced by calcite (Fig. 4a-c). Detailed BSE images reveal that the small dolomite crystals, which are found in the large dedolomite rhombs, are gathered at the rims of dedolomite crystals. Moreover, they seem to have the same size as the surrounding dolomitized matrix (Fig. 4c); (2) small dolomite crystals occurring in dedolomite crystals are scattered along the core/rim interfaces, but are not cut by the fracture across the dedolomite crystal (arrow). The small dolomite crystals are sub-euhedral to euhedral, differently oriented single crystals, which seems not relics of precursor dolomite, but another phase of dolomite growth that formed post-dated the dedolomitization (Fig. 4d-f); (3) dolomite rhombs pervasively replaced by calcite with dolomite patches scattered in calcitized dolomite (Fig. 4g-k). The dolomite crystals occur in dedolomite are sub-euhedral to anhedral with different sizes. (4) dedolomite fabric formed by internal partial or complete dissolution of dedolomite (Fig. 4j, k) rhombs. Progressive dissolution may lead to the emptying of dedolomite rhombs to form open rhombohedral pores (Fig. 41).

Detailed SEM images of zoned dedolomite and dolomite shows progressive dedolomitization process from core/rim interface to crystal core (Fig. 5a-c). The ghost of rhombic dedolomite outlined by the crystal lattice with gradual color 

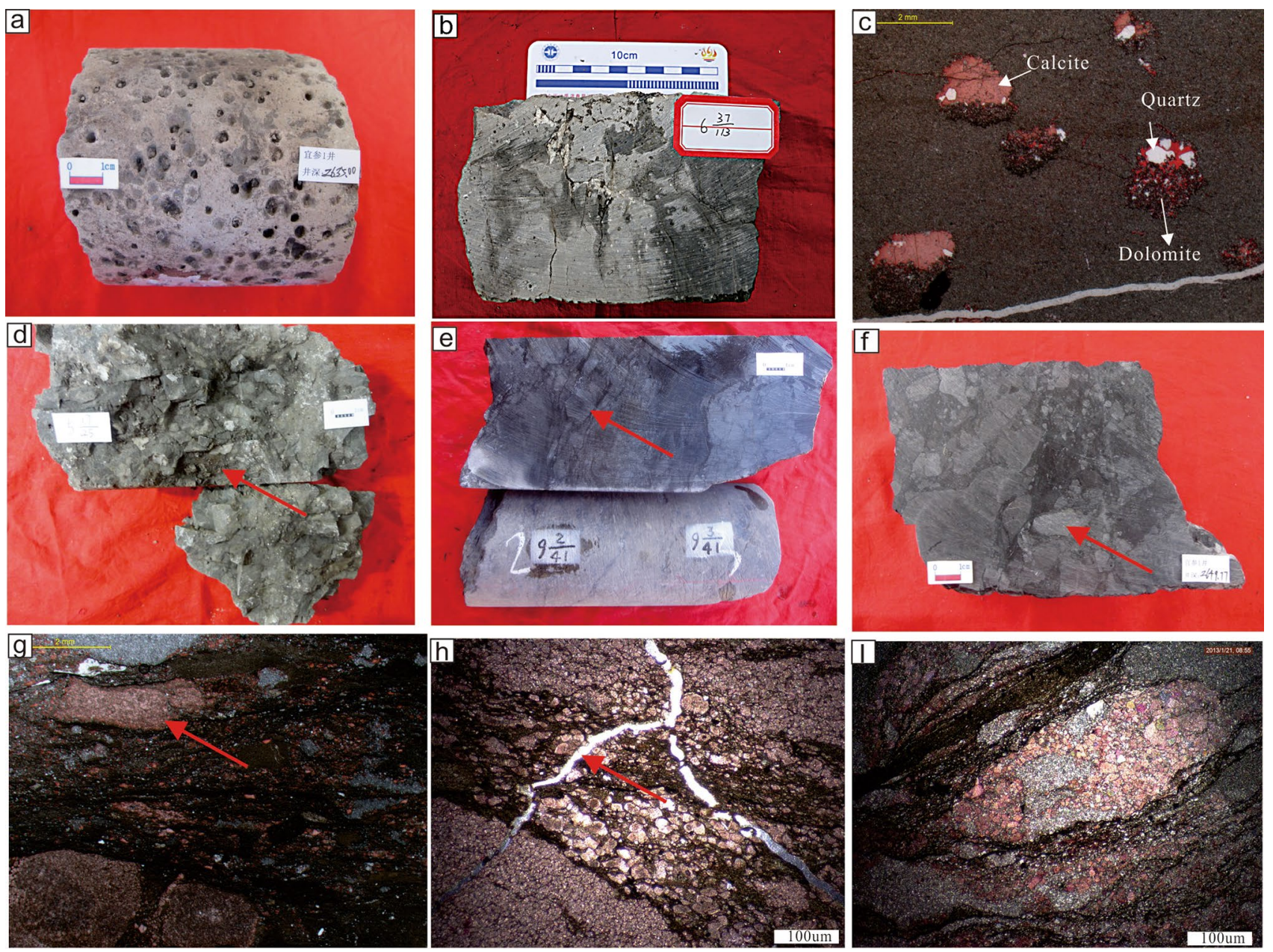

Fig. 2 Petrographic characteristics of the Ordovician Majiagou Formation of Yican 1 well in the southeastern Ordos Basin. Thin sections were stained with Alizarin Red-S. a Anhydrite nodule-bearing dolomite with anhydrite nodules dissolved to form dissolution moulds; b Anhydrite nodule-bearing dolomite with fractures filled with clay; c Anhydrite nodule-bearing dolomite with anhydrite nodules filled with calcite, dolomite and quartz; d Karst breccia with dark gray mudstone and dark brown clay (arrow) filled in the brec- cia clasts; e and f Dolomitic breccia composed of light gray clasts (arrows) and dark gray micrite matrix; $\mathbf{g}$ Microphotograph of brecciated dedolomite showing dedolomite rhombs (arrows) floating in the micrite matrix or form an aggregates; $\mathbf{h}$ Open fractures across the dolomite matrix and dedolomite aggregates (arrow); i Brecciated dedolomite showing dedolomite rhombs (arrows) floating in the micrite matrix or form an aggregates (arrows) change seems like erosional relics (Fig. 5b, the enlargement of top right of Fig. 5a), which are different from the small euhedral dolomite crystals surrounding it. In the zoned dolomite (Fig. 5c, the enlargement of bottom of Fig. 5a), $\mathrm{Mg}^{2+}$ content generally decreases from the dark gray cores to light gray rims (Fig. 5d). Although the value of point 4 shows some deviation, the general trend is consistent with the observed color changes.

\section{Crystalline limestone (crystalline dedolomite)}

The crystalline limestone shows various colors from gray to brownish red, or occurs as brownish red patchy in light gray dolostone (Fig. 6a-c). The patchy texture is more obvious due to clay concentrated among breccia. Some specimens are characterized by $\mathrm{cm}$-scale layered structures, composed of gray dolomite and brownish red calcite (Fig. 6c). Open vugs or pores presumably formed by dissolution are observed in crystalline limestone (Fig. 6a, d). The vugs and pores, which are filled by calcite or dolomite, are found in multiple dedolomitized horizons with the pore size of $0.5 \sim 2.0 \mathrm{~cm}$. The pores and vugs are common in the crystalline limestone (brownish red layer in Fig. 6e), mostly distributed in isolation or bead-like arrangement (Fig. 6e, f), but rarely observed in the dolomite horizons (gray layer in Fig. 6e).

Petrographically, the crystalline limestone is predominantly composed of xenotopic, medium to coarse, crystalline (mostly 200 to $1000 \mathrm{um}$ in diameter) calcite mosaics 
Fig. 3 SEM images and EDS diagram of dedolomite crystal and dolomite rhomb in it. a Dark gray rhomb (point 27) represents dolomite identified from the (b) EDS diagram; c Enlargment of figure a in red box showing light gray background representing calcite (dedolomite in this study) identified from the (d) EDS diagram
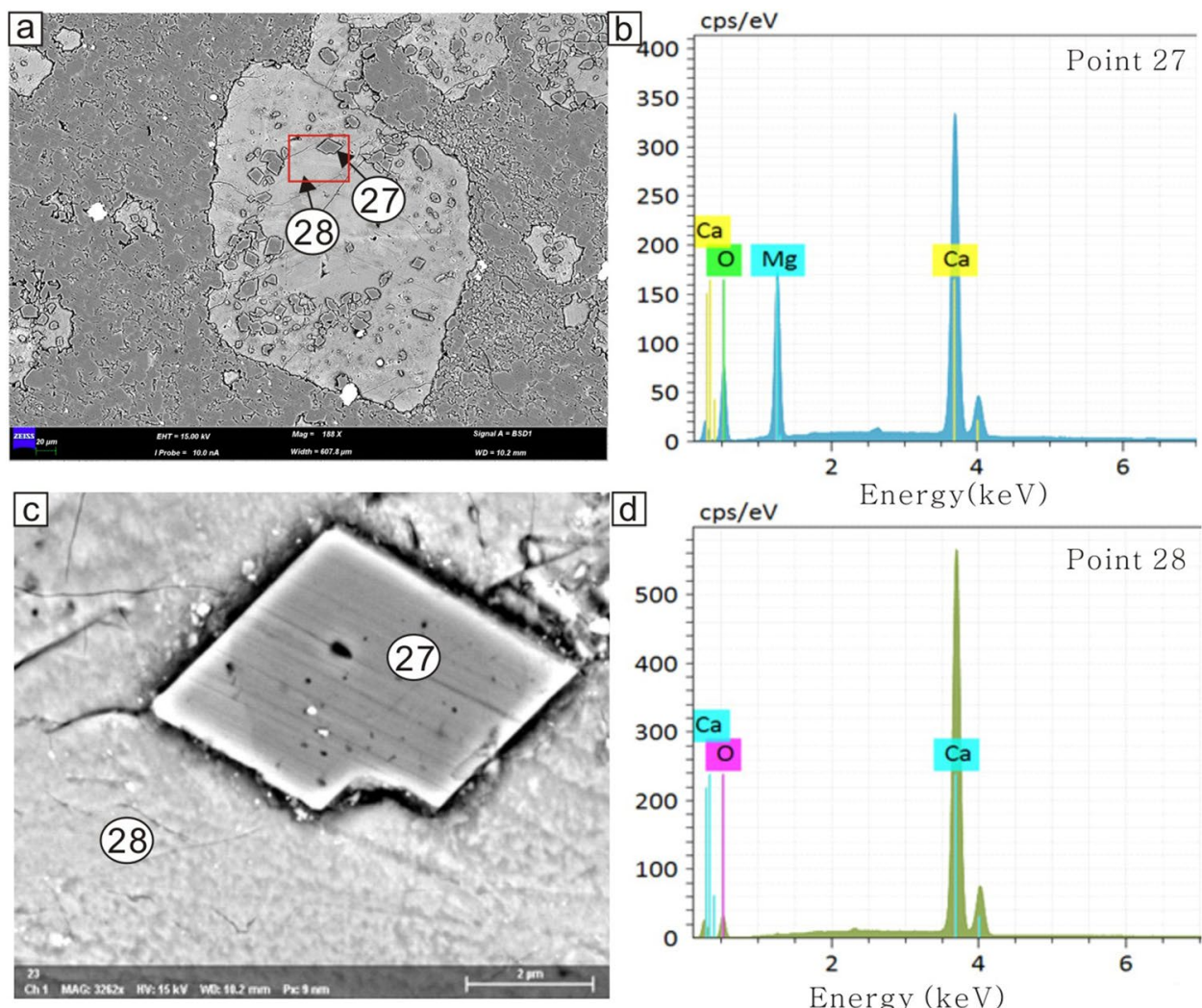

with variable amount of dolomite impurities (Fig. 6g, h). The dolomite rhombohedra boundaries are obscured by calcite but retain part of the dark, cloudy core impurities, and appeared to be relics after replacement (Fig. 6g, h), which is identified as crystalline dedolomite. The medium-coarse calcite crystals show irregular intercrystalline boundaries and are interlocked with each other to make the rock dense with low porosity (Fig. 6g, h). The intercrystalline pores are enriched in clay minerals. In some samples, the clay minerals were found to have calcitic edges (Fig. 6i). The crystalline dedolomite mainly occurs in the $\mathrm{Ma}_{5}$ member of Yi 5, Yi 9, Yi 13, Yi 16 wells.

\section{Anhydritic dolostone and dolomitic anhydrite lithofacies}

This lithofacies is mainly composed of mm-scale lamination of dominantly dolostone and anhydrite layers (Fig. 7a). Petrographically, the dolostone and anhydrite layers are interbedded displaying an abrupt contact (Fig. 7b). The very-fine bedding fractures are filled with calcite parallel to the anhydrite and dolomite layers (Fig. 7b). In some cases, the fine-grained anhydrite layers are characterized by softsediment deformation fabrics such as convolute bedding and shear folds in wavy arrangement (Fig. 7c). Another common fabric is a mosaic of "chicken-wire" texture, which is often interpreted to be indicative of a sabkha environment (Fig. 7d, e) (Kendall 1979; Sallam et al. 2019a, b). The
Majiagou Formation typically shows a lithofacies change from sabkha-type anhydrite to anhydrite-after-gypsum nodules. This change is regionally accompanied by an increasing frequency of anhydrite layer towards the lithologic base of the formation. With the increasing of anhydrite content, the anhydritic dolostone is gradually transitioned downward into dolomitic anhydrite (Figs. 7d-f). The massive and milky anhydrite is mainly distributed in and below the $\mathrm{Ma}_{4}$ member (Fig. 7f).

\section{Petrophysical data}

The petrophysical data from the Majiagou Formation in the study area shows that the maximum porosity of the reservoir is up to $10.8 \%$ and the maximum permeability is $15.45 \mathrm{mD}$ occurring in the anhydrite nodule-bearing dolomite of the $\mathrm{Ma}_{5}{ }^{1}$ sub-member except the anomalously high permeability that caused by fractures (Table 2). The dominant pore types defining good reservoir facies are anhydrite moldic pores and fractures (Figs. 2a, b). The anhydrite moldic pores are 1-2 $\mathrm{mm}$ in diameter accounting for more than 10-20\% of the cores, which mainly occurs in the $\mathrm{Ma}_{5}{ }^{1}$ to $\mathrm{Ma}_{5}{ }^{4}$ submembers as shown in Fig. 2a. The fractures occur throughout the whole cores including structural fracture, gravity seam, cracking crack (Fig. 2b) etc. When the anhydrite is transformed to gypsum, the volume is usually increased by $30 \%$, resulting in great swelling force on the surrounding 

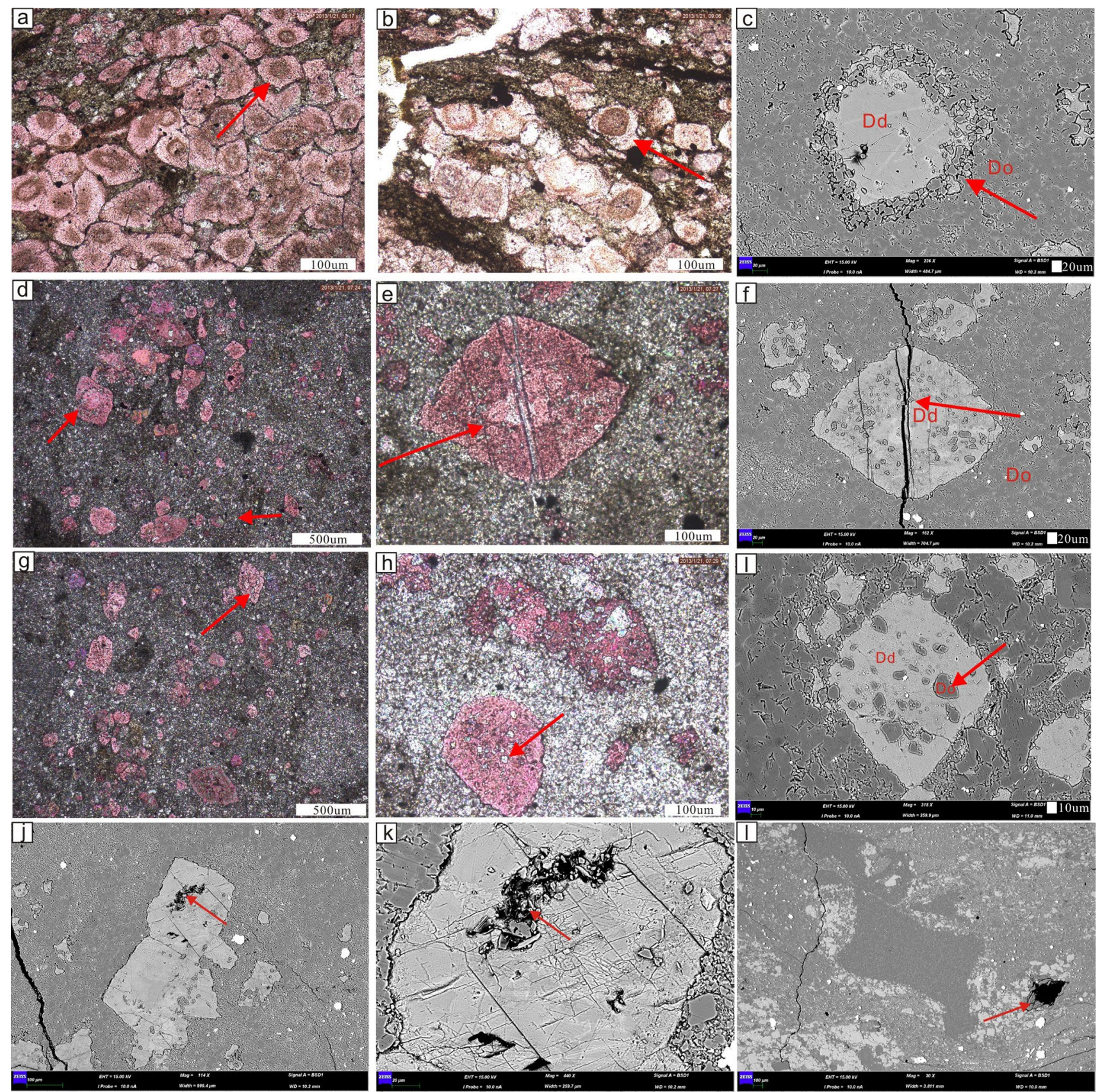

Fig. 4 Thin section photomicrographs and SEM images of dedolomites from the Majiagou Formation of Yican 1 well in the southeastern Ordos Basin. Thin sections were stained with Alizarin Red-S to discriminate calcite and dolomite. All thin sections are shown in plane-polarized light. Dd: Dedolomite; Do: Dolomite. a-c Dedolomite mimics the rhombic shape of dolomite with dolomite grains in

rock. After the gypsum is dissolved, the pressure will be released, and this process is repeated, resulting in cracking cracks in the surrounding rock matrix (Fig. 2b). Furthermore, petrophysical data show that most of the calcite samples (mainly dedolomite) have low porosity and permeability, whereas dolomite commonly correlates to high porosity the rims (arrows). d-f Dedolomite with dolomite grains at the core/ rim interface (arrows). Dedolomite crystals are cross-cut by fissures with small dolomite crystal not cut by the fissures. $\mathbf{g}-\mathbf{i}$ Dedolomite with dolomite grains scattered in the romb. $\mathbf{j}-\mathbf{l}$ Dedolomite crystals with rhombohedral pores

and permeability except some anomalously low porosity and permeability of dolomicrite (Fig. 8). SEM images also reveal that the micropores are well developed in dolomite crystals, but rarely observed in dedolomite (Figs. 5b, c).

Petrophysical data show that crystalline dedolomites have poor reservoir quality (lower porosity and lower 

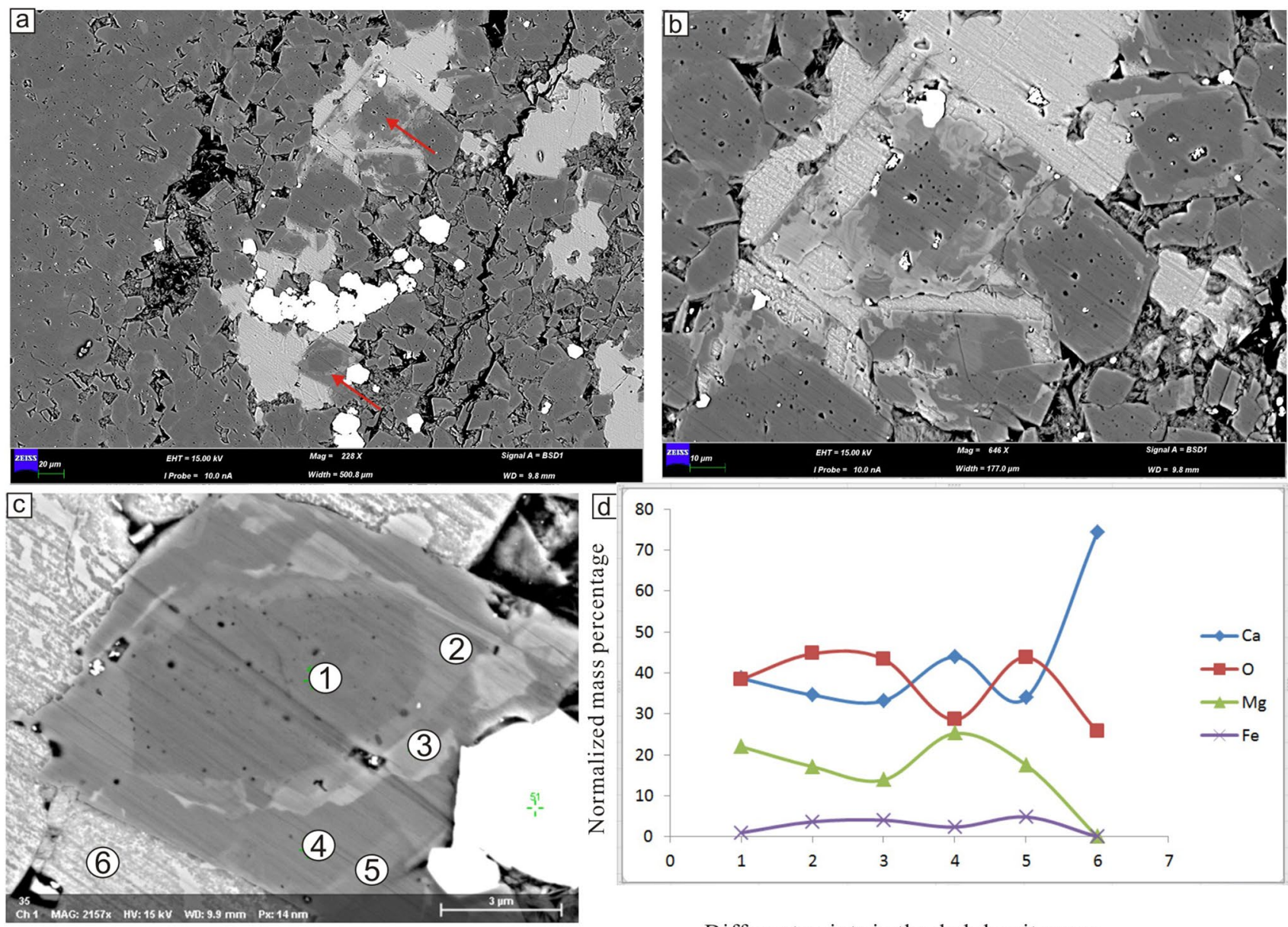

Different points in the dedolomite zone

Fig. 5 a-c SEM image of zoned dedolomite showing progressive dedolomitization process from light gray rim to dark gray core (arrows); d Elemental composition of zoned dolomite showing the element changes from point 1 to point 6

permeability) than dolomite sections throughout the Majiagou Formation (Fig. 8). The crystalline dedolomites are well developed in the wells Yi 5, Yi 9, Yi 13, Yi 16 in the southeast of the Ordos basin, where the reservoir quality is poor and the gas content is low. The effective gas bearing layer was not found in either Yi 9 or Yi 16 wells. The average porosity of Yi 16 well is $1.04 \%$ and average permeability of $0.031 \mathrm{mD}$, which is quite lower than that in wells Yican 1 and Yi 8, where the crystalline dedolomites are not developed (Table2, Fig. 8).

\section{Geochemical results}

Geochemical data related to the investigated samples are listed in Table 3, including the $\mathrm{Fe}, \mathrm{Mn}, \mathrm{Sr}$ and $\mathrm{MgO}$ content, as well as $\delta^{18} \mathrm{O}$ and $\delta^{13} \mathrm{C}$ compositions. The brecciated dedolomite is characterized by negative $\delta^{18} \mathrm{O}$, ranging from $-11.97 \%$ o to $-8.69 \%$, average of $-10.14 \%$, which is lower than the dolostone, which ranges from $-11.79 \%$ to $-7.10 \%$, average of $-8.68 \%$. The $\delta^{13} \mathrm{C}$ values of the brecciated dedolomite, ranging from $-5.14 \%$ o to $-0.45 \%$, average of $-1.97 \%$ is also negative corresponding to dolostone, which ranges from $-3.39 \%$ to $1.20 \%$, average of $-0.75 \%$. The $\delta^{18} \mathrm{O}$ and $\delta^{13} \mathrm{C}$ values of crystalline dedolomite in the Majiagou Formation vary from $-10.30 \%$ to $-8.00 \%$ (average $-8.84 \%$ ) and from $-7.50 \%$ to $-2.00 \%$ (average of $-5.86 \%$ ). The $\delta^{18} \mathrm{O}$ value of crystalline dedolomite is more negative than those of dolostone and positive to those of the brecciated dedolomite. Whereas, the $\delta^{13} \mathrm{C}$ value of crystalline dedolomite is significantly lower than those of dolostone. The $\delta^{13} \mathrm{C}$ value of brecciated dedolomite is between those of dolostone and crystalline dedolomite (Fig. 9a). The $\delta^{18} \mathrm{O}$ and $\delta^{13} \mathrm{C}$ values of the anhydritic dolostone and dolomitic anhydrite are listed, but are not discussed in this work.

The respective Fe and Mn concentrations of both brecciated dedolomite and dolostone are shown in Table 3. The Fe content of brecciated dedolomite ranges from 2875 to $15,200 \mathrm{ppm}$ (average of $8588 \mathrm{ppm}$ ) and Mn content of 33 to $225 \mathrm{ppm}$ (average of $116 \mathrm{ppm}$ ), respectively, which is substantially higher 

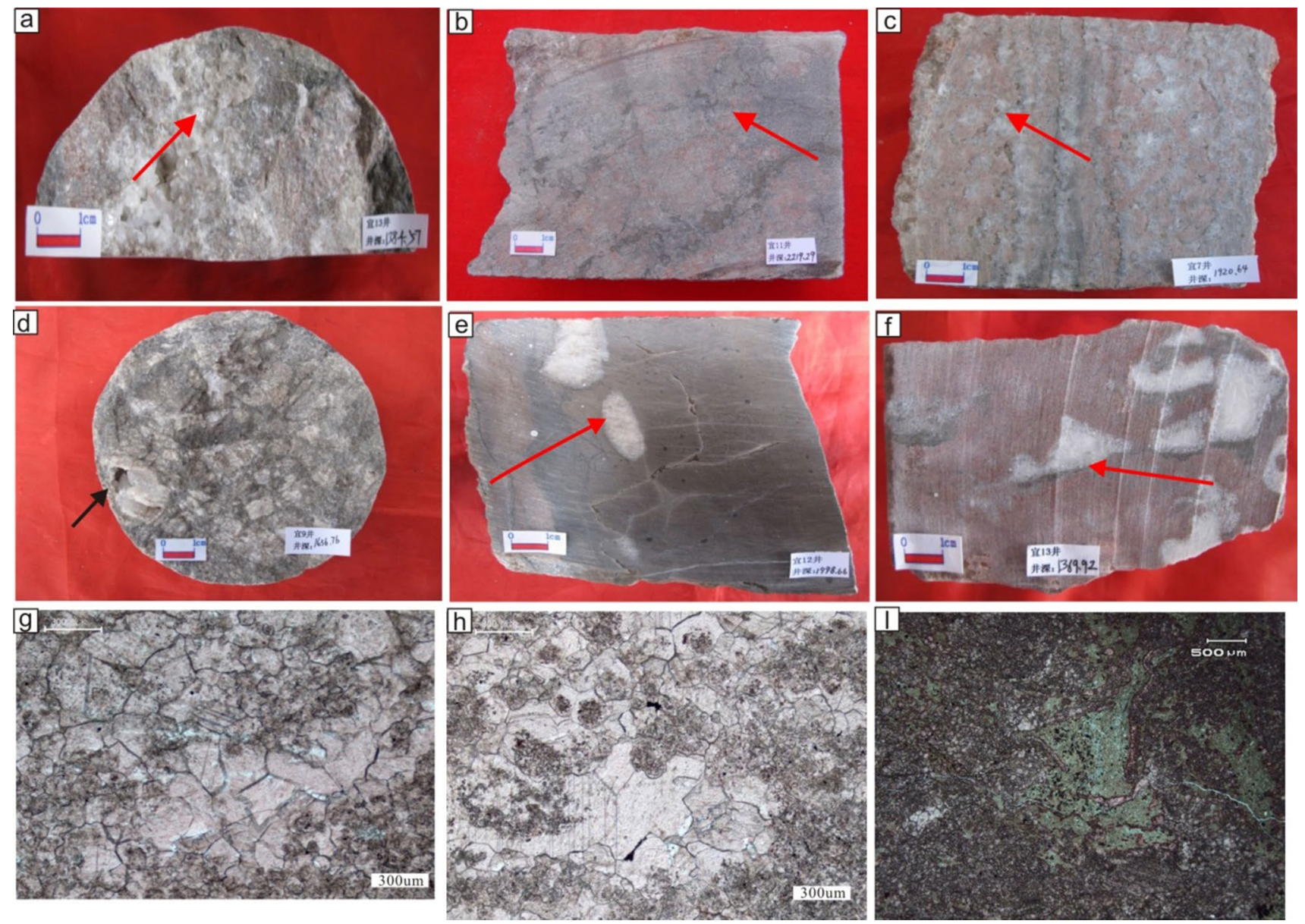

Fig. 6 The crystalline limestone of the Ordovician Majiagou Formation in southeastern Ordos Basin. a Coarsely crystalline limestone with dissolution pores, Yi 13 well, $1384.57 \mathrm{~m}, \mathrm{Ma}_{5}^{2}$; b Mediumcoarsely crystalline limestone with patchy fabric by brownish or red brownish differences, Yi 11 well, $1920.64 \mathrm{~m}, \mathrm{Ma}_{5}{ }^{1}$; c Coarsely crystalline limestone with banded fabric by brownish or red brownish color differences, Yi 7 well, $2219.29 \mathrm{~m} \mathrm{Ma}_{5}{ }^{1}$; d Crystalline limestone with dissolution pores, Yi 9 well, $1636.76 \mathrm{~m}, \mathrm{Ma}_{5}{ }_{5}$; e Crystal- line limestone with dissolution pores filled with calcite, Yi 12 well, $1998.66 \mathrm{~m}, \mathrm{Ma}_{5}{ }^{1}$; $\mathbf{f}$ Crystalline limestone with dissolution pores filled with calcite and dolomite, Yi 13 well, $1369.92 \mathrm{~m}, \mathrm{Ma}_{5}{ }^{1}$; g Photomicrograph of crystalline limestone with dolomite impurities in the cores, Yi 12 well, $2030.16 \mathrm{~m}, \mathrm{Ma}_{4}{ }^{1}$; h Photomicrograph of crystalline limestone with dolomite impurities in the cores, Yi 7 well, $1922.86 \mathrm{~m}, \mathrm{Ma}_{5}{ }^{1}$; $\mathbf{i}$ Clay mineral with calcite rim injected in finely crystalline limestone, Yi 13 well, $1357.40 \mathrm{~m}, \mathrm{Ma}_{1}{ }^{1}$ than that of dolostone, ranging from 538 to 6288 ppm (average of $2811 \mathrm{ppm}$ ) and 24 to $201 \mathrm{ppm}$ (average of $63 \mathrm{ppm}$ ) respectively (Fig. 9b). The Fe and Mn contents of anhydritic dolostone and dolomitic anhydrite show the largest spread with Fe concentration from 1663 to 23,113 ppm and Mn concentration from 44 to $418 \mathrm{ppm}$.

The average $\mathrm{Sr}$ content of the brecciated dedolomite varies from 101 to 195 ppm, average of 150, which is higher than that of dolostone ranging from 61 to 222 ppm, average of $107 \mathrm{ppm}$ (Fig. 9c). Whereas the Sr content of the anhydritic dolostone and dolomitic anhydrite ranging from 118 to $7363 \mathrm{ppm}$ and 870 to $1197 \mathrm{ppm}$, is much higher than that in both brecciated dedolomite and dolomite (Fig. 9d). 

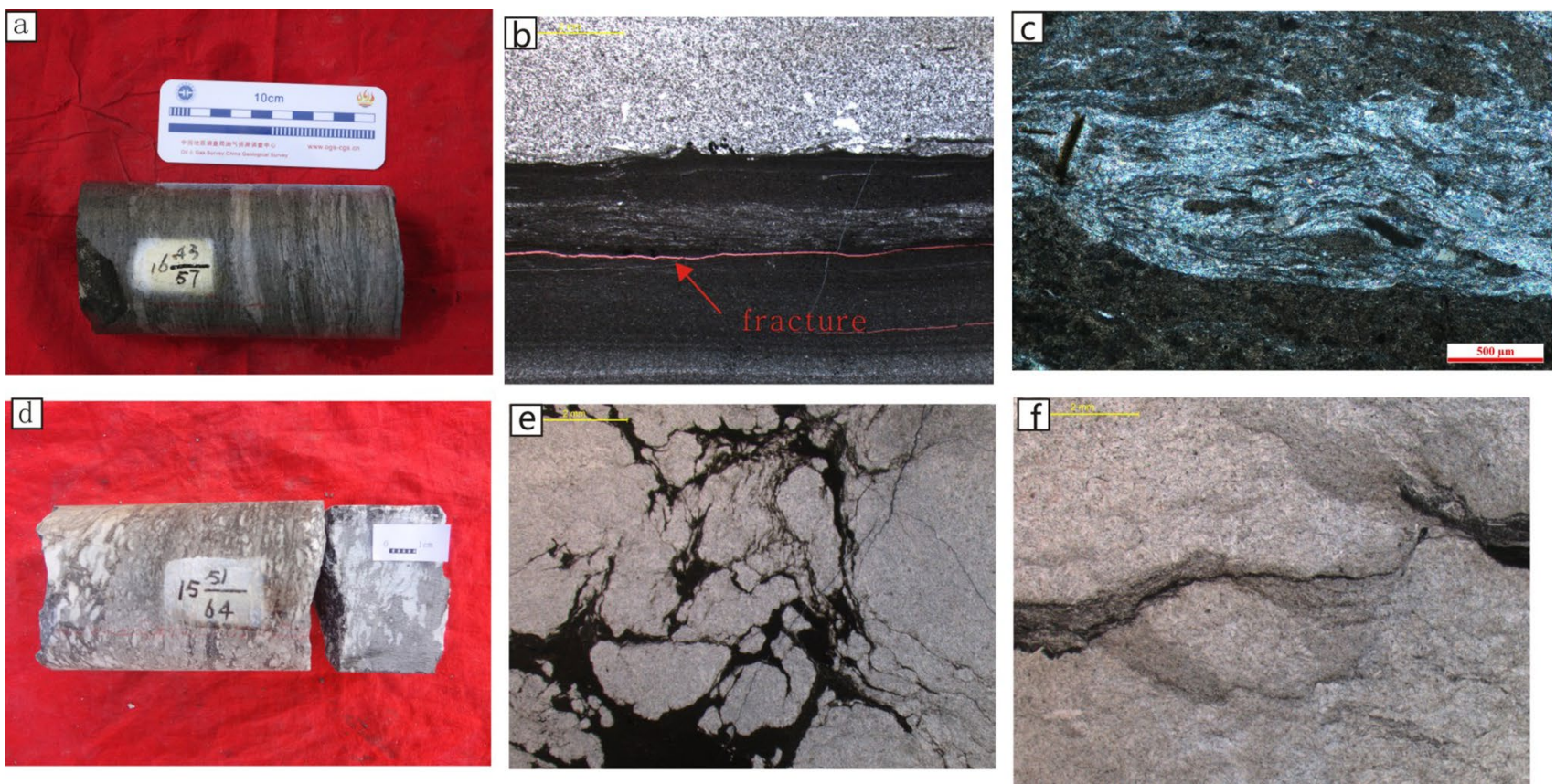

Fig. 7 Selected core photographs and microphotographs showing representative anhydrite fabrics of Yican 1 well in southeastern Ordos Basin. a Anhydrite (light gray) and dolomite (dark gray) interbedded in drill core, $3126.53 \mathrm{~m}, \mathrm{Ma}_{1}$; b Lamellar anhydrite and dolo-

\section{Discussions}

\section{Origin of the brecciated dedolomites}

In dolostone and evaporite intervals, the dissolution of evaporite under leaching of meteoric water may cause the layered collapse of dolomicrite or finely crystalline dolomite to form collapse breccias. The brecciated dedolomite (mainly occurring in Yican 1 well) is formed by the collapse of dolostones and evaporite dissolution (Fig. 2d) indicated from the following four evidences: (1) The breccias are cracked (Fig. 2d), crumped (Fig. 2e) or collapsed (Fig. 2f), and sometimes filled with dark gray mudstones and dark brown clay (Fig. 2d); (2) The clasts are mostly angular and poorly sorted as in Fig. $2 \mathrm{f}$, which are different from the syndepositional breccias, most of which may be rounded and well sorted in tidal flat environment; (3) The breccias mainly occur less than $60 \mathrm{~m}$ below unconformity, which is controlled by the hydraulic conductivity of the rocks below the unconformity.; (4)The sizes of the clasts are largely controlled by the thickness of the nonevaporative beds, which are often mm-scale as in Fig. 7a, $\mathrm{b}$ in the study area. The petrology characteristics of collapsed dolostone depend on the original lithology, which is mostly dolomicrite or finely crystalline dolostone in the study area. mite in thin section, $2962.81 \mathrm{~m}, \mathrm{Ma}_{2}$; $\mathbf{c}$ Wavy arrangement of anhydrite in dolomite, $2817.51 \mathrm{~m}, \mathrm{Ma}_{4}$; $\mathbf{d}$ Massive anhydrite in drill core, $2969.58 \mathrm{~m}, \mathrm{Ma}_{2}$; e Lump anhydrite in thin section, $2725.03 \mathrm{~m}, \mathrm{Ma} 5 ; \mathbf{f}$ Massive anhydrite in thin section, $2963.69 \mathrm{~m}, \mathrm{Ma}_{2}$

In evaporite horizons, the breccias are the typical end result of evaporite dissolution (Swennen et al. 1990; Warren 2016). Collapse breccias resulting from evaporite dissolution by fresh water flushing has been genetically associated with dedolomitized sections in many previous case studies (Arenas et al. 1999; Rameil 2008). Brecciation is almost synchronous with the evaporite dissolution driven by meteoric-derived fluids undersaturated with respect to calcium sulphate following uplift in the Late Ordovician, because both the vugs and cavities in inter-clast pores are partly filled by yellow-brown clay (Figs. 2d, 6i). The anhydrite nodulebearing dolostone occurs at the top of the Majiagou Formation (Fig. 2a-c). The nodular morphology suggests precursor gypsum or anhydrite, which is dissolved by meteoric water during an episode of subaerial exposure during the Caledonian orogeny (He 2003).

Dedolomitization is characterized by rhombohedral replacement of dolomite by calcite, which has been stained by Alizarin Red S but remain the rhombic shape indicative of precursor dolomite (Figs. 2g-i). In the dedolomitization process, the rhombic shape of precursor dolomite commonly remained, which is due to different crystal lattice energy of dolomite and calcite. $\mathrm{Mg}^{2+}$ has ionic radius of $0.75 \AA$, which is $74.26 \%$ that of $\mathrm{Ca}^{2+}$, with ionic radius of about $1.01 \AA$. Because of its smaller ionic radius, $\mathrm{Mg}-\mathrm{O}$ interionic distance is smaller than that of $\mathrm{Ca}-\mathrm{O}$. The smaller an interionic distance is, the stronger the ionic strength effect 
Table 2 Petrophysical data of Ordovician Majiagou formation of Yican 1 well, Yi8 and Yi 16 wells

\begin{tabular}{|c|c|c|c|c|c|c|c|}
\hline No & Samples & Depth & Lithology & Formation & Porosity (\%) & $\begin{array}{l}\text { Permeability } \\
(10-3 \mu \mathrm{m} 2)\end{array}$ & Note \\
\hline 1 & 68 & 2633.36 & Brecciated Dedolomite & $\mathrm{Ma}_{5}{ }^{1}$ & 0.12 & 0.10 & \\
\hline 2 & 72 & 2634.91 & Dolomite & $\mathrm{Ma}_{5}{ }^{1}$ & 10.80 & 15.45 & \\
\hline 3 & 78 & 2637.51 & Dolomite & $\mathrm{Ma}_{5}{ }^{2}$ & 1.10 & 0.25 & \\
\hline 4 & 82 & 2637.61 & Brecciated Dedolomite & $\mathrm{Ma}_{5}^{2}$ & 0.12 & 0.15 & \\
\hline 5 & 84 & 2638.97 & Brecciated Dedolomite & $\mathrm{Ma}_{5}^{2}$ & 1.10 & 0.02 & \\
\hline 6 & 86 & 2639.93 & Brecciated Dedolomite & $\mathrm{Ma}_{5}^{2}$ & 1.10 & 0.01 & \\
\hline 7 & 88 & 2640.37 & Dolomite & $\mathrm{Ma}_{5}^{2}$ & 2.65 & 3.86 & fracture \\
\hline 8 & 90 & 2640.9 & Dolomite & $\mathrm{Ma}_{5}^{2}$ & 2.10 & 0.29 & \\
\hline 9 & 92 & 2641.44 & Dolomite & $\mathrm{Ma}_{5}^{2}$ & 3.60 & 14.64 & fracture \\
\hline 10 & 104 & 2645.32 & Brecciated Dedolomite & $\mathrm{Ma}_{5}{ }^{1}$ & 0.10 & 0.03 & \\
\hline 11 & 108 & 2646.64 & Brecciated Dedolomite & $\mathrm{Ma}_{5}{ }^{2}$ & 0.09 & 0.07 & \\
\hline 12 & 110 & 2649.13 & Brecciated Dedolomite & $\mathrm{Ma}_{5}^{2}$ & 0.60 & 0.06 & \\
\hline 13 & 112 & 2650.18 & Brecciated Dedolomite & $\mathrm{Ma}_{5}^{2}$ & 0.11 & 0.03 & \\
\hline 14 & 113 & 2653.49 & Dolomite & $\mathrm{Ma}_{5}{ }^{3}$ & 3.50 & 0.02 & \\
\hline 15 & 114 & 2655.08 & Brecciated Dedolomite & $\mathrm{Ma}_{5}{ }^{3}$ & 1.30 & 2.59 & \\
\hline 16 & 118 & 2655.53 & Brecciated Dedolomite & $\mathrm{Ma}_{5}{ }^{3}$ & 0.68 & 0.03 & \\
\hline 17 & 122 & 2677.56 & Brecciated Dedolomite & $\mathrm{Ma}_{5}{ }^{4}$ & 2.70 & & fracture \\
\hline 18 & 124 & 2679.12 & Dolomite & $\mathrm{Ma}_{5}{ }^{4}$ & 0.30 & 0.01 & \\
\hline 19 & 128 & 2680.24 & Brecciated Dedolomite & $\mathrm{Ma}_{5}{ }^{4}$ & 0.79 & 0.02 & \\
\hline 20 & 132 & 2681.13 & Brecciated Dedolomite & $\mathrm{Ma}_{5}{ }^{4}$ & 0.06 & 0.02 & \\
\hline 21 & 136 & 2683.75 & Brecciated Dedolomite & $\mathrm{Ma}_{5}{ }^{4}$ & 0.77 & 0.42 & \\
\hline 22 & 140 & 2684.86 & Brecciated Dedolomite & $\mathrm{Ma}_{5}{ }^{4}$ & 0.19 & 0.04 & \\
\hline 23 & 146 & 2686 & Brecciated Dedolomite & $\mathrm{Ma}_{5}{ }^{4}$ & 0.06 & 0.02 & \\
\hline 24 & 150 & 2688 & Brecciated Dedolomite & $\mathrm{Ma}_{5}{ }^{4}$ & 1.48 & 27.75 & fracture \\
\hline 25 & 154 & 2688.86 & Brecciated Dedolomite & $\mathrm{Ma}_{5}^{4}$ & 0.33 & 0.14 & \\
\hline 26 & 156 & 2724.48 & Dolomite & $\mathrm{Ma}_{5}{ }^{6}$ & 0.40 & 0.01 & \\
\hline 27 & 158 & 2725.52 & Dolomite & $\mathrm{Ma}_{5}{ }^{6}$ & 0.12 & 5.81 & fracture \\
\hline 28 & 162 & 2728.72 & Anhydrite dolomite & $\mathrm{Ma}_{5}{ }^{6}$ & 0.08 & 0.01 & \\
\hline 29 & 166 & 2732.93 & Dolomite & $\mathrm{Ma}_{5}{ }^{6}$ & 0.40 & 0.13 & \\
\hline 30 & 178 & 2806.84 & Dolomite & $\mathrm{Ma}_{4}$ & 0.09 & 0.02 & \\
\hline 31 & 182 & 2807.57 & Dolomite & $\mathrm{Ma}_{4}$ & 0.05 & 0.01 & \\
\hline 32 & 186 & 2808.49 & Dolomite & $\mathrm{Ma}_{4}$ & 0.06 & 0.01 & \\
\hline 33 & 188 & 2809.1 & Dolomite & $\mathrm{Ma}_{4}$ & 0.90 & 0.01 & \\
\hline 34 & 190 & 2814.86 & Dolomite & $\mathrm{Ma}_{4}$ & 0.08 & 0.01 & \\
\hline 35 & 206 & 2818.31 & Dolomite & $\mathrm{Ma}_{4}$ & 0.07 & 0.01 & \\
\hline 36 & 214 & 2819.91 & Dolomite & $\mathrm{Ma}_{4}$ & 0.06 & 0.02 & \\
\hline 37 & 222 & 2821.46 & Dolomite & $\mathrm{Ma}_{4}$ & 0.07 & 0.01 & \\
\hline 38 & 226 & 2822.26 & Dolomite & $\mathrm{Ma}_{4}$ & 0.08 & 0.02 & \\
\hline 39 & 246 & 2953.57 & Dolomite & $\mathrm{Ma}_{2}$ & 0.13 & 0.01 & \\
\hline 40 & 250 & 2954.83 & Dolomite & $\mathrm{Ma}_{2}$ & 0.48 & 0.03 & \\
\hline 41 & 258 & 2957 & Dolomite & $\mathrm{Ma}_{2}$ & 0.13 & 25.51 & fracture \\
\hline 42 & 262 & 2958.29 & Dolomite & $\mathrm{Ma}_{2}$ & 2.10 & 0.04 & \\
\hline 43 & 266 & 2958.87 & Dolomite & $\mathrm{Ma}_{2}$ & 2.40 & 0.01 & \\
\hline 44 & 270 & 2961.34 & Dolomite & $\mathrm{Ma}_{2}$ & 0.75 & 0.01 & \\
\hline 45 & 274 & 2962.18 & Dolomitic anhydrite & $\mathrm{Ma}_{2}$ & 1.44 & 0.04 & \\
\hline 46 & 278 & 2964.34 & Dolomitic anhydrite & $\mathrm{Ma}_{2}$ & 0.78 & 0.04 & \\
\hline 47 & 282 & 2965.97 & Dolomitic anhydrite & $\mathrm{Ma}_{2}$ & 0.56 & 0.62 & \\
\hline 48 & 284 & 2966.67 & Dolomite & $\mathrm{Ma}_{2}$ & 0.50 & 0.01 & \\
\hline 49 & 286 & 2967.34 & Anhydrite dolomite & $\mathrm{Ma}_{2}$ & 0.34 & & fracture \\
\hline 50 & 290 & 2968.52 & Dolomitic anhydrite & $\mathrm{Ma}_{2}$ & 1.10 & & fracture \\
\hline
\end{tabular}


Table 2 (continued)

\begin{tabular}{|c|c|c|c|c|c|c|c|}
\hline No & Samples & Depth & Lithology & Formation & Porosity (\%) & $\begin{array}{l}\text { Permeability } \\
(10-3 \mu \mathrm{m} 2)\end{array}$ & Note \\
\hline 51 & 294 & 2969.38 & Anhydrite dolomite & $\mathrm{Ma}_{2}$ & 0.59 & & fracture \\
\hline 52 & 298 & 2970.9 & Anhydrite dolomite & $\mathrm{Ma}_{2}$ & 0.74 & 0.02 & \\
\hline 53 & 302 & 3120.15 & Anhydrite dolomite & $\mathrm{Ma}_{1}$ & 0.91 & 0.05 & \\
\hline 54 & 306 & 3121.3 & Anhydrite dolomite & $\mathrm{Ma}_{1}$ & 0.05 & 0.05 & \\
\hline 55 & 310 & 3122.59 & Anhydrite dolomite & $\mathrm{Ma}_{1}$ & 0.37 & 0.02 & \\
\hline 56 & 316 & 3124.53 & Anhydrite dolomite & $\mathrm{Ma}_{1}$ & 0.43 & & fracture \\
\hline 57 & 320 & 3125.87 & Anhydrite dolomite & $\mathrm{Ma}_{1}$ & 1.05 & 0.24 & \\
\hline 58 & 324 & 3127.16 & Anhydrite dolomite & $\mathrm{Ma}_{1}$ & 1.46 & 0.01 & \\
\hline \multirow[t]{4}{*}{59} & 326 & 3127.83 & Anhydrite dolomite & $\mathrm{Ma}_{1}$ & 1.03 & 0.02 & \\
\hline & Min & & & & 0.05 & 0.01 & \\
\hline & Max & & & & 10.80 & 27.75 & \\
\hline & Average & & & & 1.09 & 2.26 & \\
\hline 60 & Yi8 & 2248.58 & Dolomite & $\mathrm{Ma}_{5}{ }^{1}$ & 6.22 & 0.062 & \\
\hline 61 & Yi8 & 2248.72 & Dolomite & $\mathrm{Ma}_{5}{ }^{1}$ & 6.19 & 0.065 & \\
\hline 62 & Yi8 & 2248.89 & Dolomite & $\mathrm{Ma}_{5}{ }^{1}$ & 4.42 & 0.054 & \\
\hline 63 & Yi8 & 2249.23 & Dolomite & $\mathrm{Ma}_{5}{ }^{1}$ & 2.45 & 0.023 & \\
\hline 64 & Yi8 & 2249.57 & Dolomite & $\mathrm{Ma}_{5}{ }^{1}$ & 6 & 0.062 & \\
\hline \multirow[t]{2}{*}{65} & Yi8 & 2249.73 & Dolomite & $\mathrm{Ma}_{5}{ }^{1}$ & 5.78 & 0.066 & \\
\hline & l & / & Average & l & 5.2 & 0.055 & \\
\hline 66 & Yi16 & 2380.65 & Crystalline dedolomite & $\mathrm{Ma}_{5}{ }^{1}$ & 1.1 & 0.021 & \\
\hline 67 & Yi16 & 2381.94 & Crystalline dedolomite & $\mathrm{Ma}_{5}{ }^{1}$ & 1 & 0.018 & \\
\hline 68 & Yi16 & 2382.39 & Crystalline dedolomite & $\mathrm{Ma}_{5}{ }^{1}$ & 0.9 & 0.014 & \\
\hline 69 & Yi16 & 2382.59 & Crystalline dedolomite & $\mathrm{Ma}_{5}{ }^{1}$ & 1.1 & 0.015 & \\
\hline 70 & Yi16 & 2387.16 & Crystalline dedolomite & $\mathrm{Ma}_{5}{ }^{1}$ & 1.3 & 0.029 & \\
\hline 71 & Yi16 & 2388.46 & Crystalline dedolomite & $\mathrm{Ma}_{5}{ }^{1}$ & 1.2 & 0.109 & \\
\hline \multirow[t]{2}{*}{72} & Yi16 & 2390.6 & Crystalline dedolomite & $\mathrm{Ma}_{5}{ }^{1}$ & 0.7 & 0.013 & \\
\hline & l & l & Average & & 1.04 & 0.031 & \\
\hline
\end{tabular}

is. The calcite, therefore, rarely destroys the dolomite fabric in dedolomitization process, but remains its rhombic shape.

Petrographically, the small dolomite crystals that are found in the large dedolomite rhombs at the rims or along core/rim interfaces are euhedral to subhedral, differentially oriented single crystals, which seem not to be remnants of a

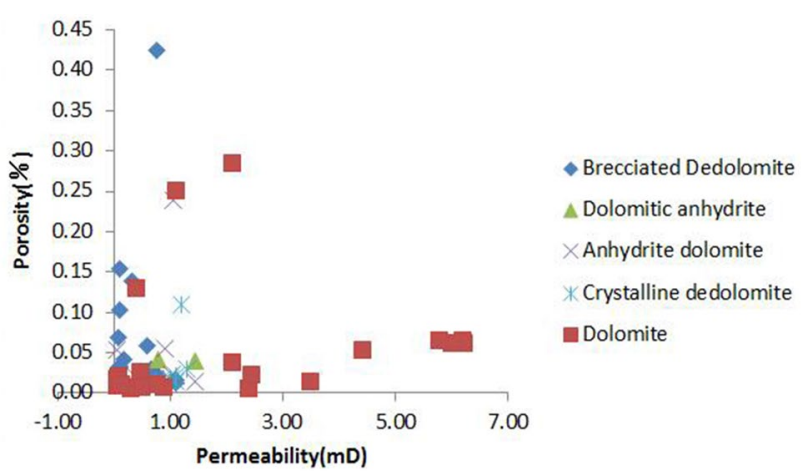

Fig. 8 Crossplot of porosity and permeability in Yican 1 well former, larger dolomite crystal, but another phase of dolomite growth that post-dated dedolomitization. If these are relics of precursor dolomite, they must be cut by the fractures together with calcitized dolomite that cross it (Fig. 4f). The small dolomite crystals are abundant and seem to have the same size with the surrounding dolomitized matrix, which would mean that dedolomitization was followed by a second, pervasive dolomitization event that only spares the cores of large dedolomite crystal.

Many case studies of dedolmitization have been documented in the literature (e.g., Sibley 1980; Khalaf and Abdal 1993; Rains and Dewers 1997; Nader et al. 2008). Most convincing and commonly known of dedolomitization is certainly a dolomite rhombohedron, being partially replaced by equicrystalline anhedral calcite. Schoenherr et al. (2018) summarizes the most common dedolomite microtextures: (1) the dolomite is totally replaced by anhedral calcite in mosaic texture; (2) the dolomite is selectively replaced by calcite at rims or cores of the rhombohedron; (3) the dolomite is partly replaced by calcite with dolomite poikilotopic inclusions in dedolomite rhombohedra. The above petrographic features 
Table 3 Geochemistry data of Ordovician Majiagou formation in southeastern Ordos Basin

\begin{tabular}{|c|c|c|c|c|c|c|c|c|c|c|}
\hline & Samples & Well & Depth (m) & Lithology & $\delta^{18} \mathrm{O}(\%)$ & $\delta^{13} \mathrm{C}(\%)$ & $\mathrm{Fe}(\mathrm{ppm})$ & $\mathrm{Mn}(\mathrm{ppm})$ & $\mathrm{Sr}(\mathrm{ppm})$ & $\overline{\mathrm{MgO}(\%)}$ \\
\hline 1 & 82 & Yican 1 & 2637.61 & Brecciated Dedolomite & -10.62 & -5.14 & 15,200 & 116 & 152 & 1 \\
\hline 2 & 84 & Yican 1 & 2638.97 & Brecciated Dedolomite & -10.44 & -4.39 & 8363 & 156 & 169 & 4 \\
\hline 3 & 104 & Yican 1 & 2645.32 & Brecciated Dedolomite & -9.54 & -1.74 & 9038 & 170 & 135 & 12 \\
\hline 4 & 136 & Yican 1 & 2683.75 & Brecciated Dedolomite & -11.97 & & 7275 & 46 & 141 & 1 \\
\hline 5 & 94 & Yican 1 & 2641.86 & Brecciated Dedolomite & -10.97 & -0.45 & & & & \\
\hline 6 & 108 & Yican 1 & 2646.64 & Brecciated Dedolomite & -9.77 & -1.44 & 8313 & 225 & 102 & 18 \\
\hline 7 & 150 & Yican 1 & 2688.00 & Brecciated Dedolomite & -9.89 & -1.01 & 4775 & 115 & 165 & 18 \\
\hline 8 & 122 & Yican 1 & 2677.56 & Brecciated Dedolomite & -8.69 & -0.86 & 13,950 & 99 & 141 & 11 \\
\hline 9 & 146 & Yican 1 & 2686.00 & Brecciated Dedolomite & -10.15 & -3.31 & 13,750 & 140 & & 10 \\
\hline 10 & 154 & Yican 1 & 2688.86 & Brecciated Dedolomite & -9.88 & -1.95 & 2875 & 33 & & \\
\hline 11 & 118 & Yican 1 & 2655.53 & Brecciated Dedolomite & -10.24 & -1.09 & 4175 & 107 & 101 & 4 \\
\hline 12 & 112 & Yican 1 & 2650.18 & Brecciated Dedolomite & -9.90 & -1.94 & 6638 & 145 & 157 & 8 \\
\hline 13 & 128 & Yican 1 & 2680.24 & Brecciated Dedolomite & -9.62 & -0.52 & 10,375 & 81 & 189 & 2 \\
\hline \multirow[t]{4}{*}{14} & \multirow[t]{4}{*}{132} & Yican 1 & 2681.13 & Brecciated Dedolomite & -10.28 & -1.73 & 6913 & 79 & 195 & 11 \\
\hline & & Yican 1 & 2688.86 & Max & -8.69 & -0.45 & 15,200 & 225 & 195 & 18 \\
\hline & & Yican 1 & 2637.61 & Min & -11.97 & -5.14 & 2875 & 33 & 101 & 1 \\
\hline & & Yican 1 & 2664.26 & Average & -10.14 & -1.97 & 8588 & 116 & 150 & 8 \\
\hline 15 & 170 & Yican 1 & 2731.40 & Dolomite & -10.05 & -2.77 & 2963 & 83 & 152 & 20 \\
\hline 16 & 174 & Yican 1 & 2731.83 & Dolomite & -8.85 & -2.43 & 3075 & 70 & 143 & 21 \\
\hline 17 & 90 & Yican 1 & 2640.90 & Dolomite & -11.79 & 1.20 & 4906 & 201 & 99 & 20 \\
\hline 18 & 92 & Yican 1 & 2641.44 & Dolomite & -8.04 & -0.59 & & & & \\
\hline 19 & 158 & Yican 1 & 2725.52 & Dolomite & -7.88 & -3.39 & 4975 & 104 & 164 & 17 \\
\hline 20 & 178 & Yican 1 & 2806.84 & Dolomite & -8.34 & 0.42 & 2100 & 40 & 106 & 22 \\
\hline 21 & 182 & Yican 1 & 2807.57 & Dolomite & -7.97 & 0.37 & 2325 & 37 & 122 & 21 \\
\hline 22 & 186 & Yican 1 & 2808.49 & Dolomite & -10.32 & -1.93 & & & & \\
\hline 23 & 190 & Yican 1 & 2814.86 & Dolomite & -8.77 & -0.27 & 1025 & 36 & 83 & 23 \\
\hline 24 & 194 & Yican 1 & 2815.81 & Dolomite & -8.63 & -0.35 & 3138 & 31 & 72 & 21 \\
\hline 25 & 198 & Yican 1 & 2816.60 & Dolomite & -8.53 & -0.13 & 1513 & 27 & 222 & 23 \\
\hline 26 & 202 & Yican 1 & 2817.46 & Dolomite & -8.81 & -0.21 & 1338 & 30 & 142 & 21 \\
\hline 27 & 206 & Yican 1 & 2818.31 & Dolomite & -8.42 & -0.09 & 825 & 27 & 67 & 23 \\
\hline 28 & 214 & Yican 1 & 2819.91 & Dolomite & -8.99 & -0.14 & 663 & 30 & 79 & 22 \\
\hline 29 & 218 & Yican 1 & 2820.71 & Dolomite & -8.53 & -0.15 & 988 & 24 & 75 & 23 \\
\hline 30 & 222 & Yican 1 & 2821.46 & Dolomite & -8.75 & -0.01 & 588 & 25 & 76 & 24 \\
\hline 31 & 226 & Yican 1 & 2822.26 & Dolomite & -8.56 & -0.04 & 538 & 26 & 75 & 20 \\
\hline 32 & 228 & Yican 1 & 2823.70 & Dolomite & -7.80 & -0.14 & & & & \\
\hline 33 & 232 & Yican 1 & 2945.62 & Dolomite & -7.10 & -3.11 & & & & \\
\hline 34 & 234 & Yican 1 & 2949.94 & Dolomite & -8.64 & -0.88 & 4525 & 83 & 86 & 23 \\
\hline 35 & 238 & Yican 1 & 2950.72 & Dolomite & -8.37 & -0.77 & 3938 & 72 & 70 & 20 \\
\hline 36 & 242 & Yican 1 & 2951.52 & Dolomite & -8.52 & -0.92 & 6288 & 75 & 122 & 22 \\
\hline 37 & 246 & Yican 1 & 2953.57 & Dolomite & -8.21 & -0.70 & 4188 & 67 & 68 & 20 \\
\hline 38 & 250 & Yican 1 & 2954.83 & Dolomite & -8.74 & -0.46 & 3388 & 85 & 180 & 22 \\
\hline 39 & 254 & Yican 1 & 2955.85 & Dolomite & -8.17 & -0.41 & 2575 & 59 & 61 & 20 \\
\hline 40 & 258 & Yican 1 & 2957.00 & Dolomite & -8.21 & -0.62 & 4288 & 78 & 70 & 22 \\
\hline 41 & 262 & Yican 1 & 2958.29 & Dolomite & -9.46 & -0.83 & 2825 & 81 & 157 & 21 \\
\hline 42 & 266 & Yican 1 & 2959.44 & Dolomite & -9.26 & -0.90 & 2425 & 88 & 120 & 23 \\
\hline 43 & 270 & Yican 1 & 2961.34 & Dolomite & -7.95 & -1.54 & 4888 & 84 & 69 & 20 \\
\hline & & Yican 1 & 2961.34 & Max & -7.10 & 1.20 & 6288 & 201 & 222 & 24 \\
\hline & & Yican 1 & 2640.90 & Min & -11.79 & -3.39 & 538 & 24 & 61 & 17 \\
\hline & & Yican 1 & 2844.69 & Average & -8.68 & -0.75 & 2811 & 63 & 107 & 21 \\
\hline 44 & 162 & Yican 1 & 2728.72 & Anhydrite dolomite & -9.37 & -2.39 & 3750 & 71 & 7363 & 17 \\
\hline
\end{tabular}


Table 3 (continued)

\begin{tabular}{|c|c|c|c|c|c|c|c|c|c|c|}
\hline & Samples & Well & Depth (m) & Lithology & $\delta^{18} \mathrm{O}(\% \mathrm{o})$ & $\delta^{13} \mathrm{C}(\% \mathrm{o})$ & $\mathrm{Fe}(\mathrm{ppm})$ & $\mathrm{Mn}(\mathrm{ppm})$ & $\mathrm{Sr}(\mathrm{ppm})$ & $\operatorname{MgO}(\%)$ \\
\hline 45 & 166 & Yican 1 & 2730.60 & Anhydrite dolomite & -8.70 & -2.27 & 2550 & 70 & 291 & 18 \\
\hline 46 & 286 & Yican 1 & 2967.34 & Anhydrite dolomite & -7.63 & -2.41 & 7413 & 85 & 189 & 16 \\
\hline 47 & 294 & Yican 1 & 2969.38 & Anhydrite dolomite & -7.88 & 0.48 & 2200 & 52 & 209 & 21 \\
\hline 48 & 298 & Yican 1 & 2970.90 & Anhydrite dolomite & -7.59 & -0.81 & 1663 & 44 & 877 & 14 \\
\hline 49 & 302 & Yican 1 & 3120.15 & Anhydrite dolomite & -8.21 & -3.26 & 8013 & 99 & 1635 & 10 \\
\hline 50 & 306 & Yican 1 & 3121.30 & Anhydrite dolomite & -7.77 & -3.30 & 9675 & 117 & 1320 & 10 \\
\hline 51 & 310 & Yican 1 & 3122.59 & Anhydrite dolomite & -7.84 & -3.25 & 17,450 & 139 & 832 & 11 \\
\hline 52 & 316 & Yican 1 & 3124.53 & Anhydrite dolomite & -8.07 & -3.92 & 19,413 & 258 & 264 & 15 \\
\hline 53 & 320 & Yican 1 & 3125.87 & Anhydrite dolomite & -8.02 & -4.90 & 23,113 & 258 & 118 & 12 \\
\hline 54 & 324 & Yican 1 & 3127.16 & Anhydrite dolomite & -7.50 & -0.90 & 9913 & 411 & 137 & 19 \\
\hline \multirow[t]{4}{*}{55} & 326 & Yican 1 & 3127.83 & Anhydrite dolomite & -7.55 & -0.83 & 10,963 & 418 & 269 & 17 \\
\hline & & Yican 1 & & Max & -7.50 & 0.48 & 23,113 & 418 & 7363 & 21 \\
\hline & & Yican 1 & & Min & -9.37 & -4.90 & 1663 & 44 & 118 & 10 \\
\hline & & Yican 1 & & Average & -8.07 & -2.30 & 10,063 & 177 & 1499 & 15 \\
\hline 56 & 274 & Yican 1 & 2962.18 & Dolomitic anhydrite & -7.98 & -2.28 & 2088 & 26 & 1197 & 4 \\
\hline 57 & 278 & Yican 1 & 2964.34 & Dolomitic anhydrite & -7.55 & -0.40 & 1427 & 29 & 870 & 8 \\
\hline 58 & 282 & Yican 1 & 2965.97 & Dolomitic anhydrite & -7.77 & -2.97 & 7288 & 58 & 984 & 5 \\
\hline \multirow[t]{4}{*}{59} & 290 & Yican 1 & 2968.52 & Dolomitic anhydrite & -7.61 & -2.99 & 4425 & 38 & 1036 & 4 \\
\hline & & Yican 1 & & Max & -7.55 & -0.40 & 7288 & 58 & 1197 & 8 \\
\hline & & Yican 1 & & Min & -7.98 & -2.99 & 1427 & 26 & 870 & 4 \\
\hline & & Yican 1 & & Average & -7.74 & -2.00 & 3990 & 39 & 1025 & 5 \\
\hline 60 & Yi13 & Yi13 & 1356.02 & Crystalline dedolomite & -10.30 & -2.00 & & & & \\
\hline 61 & Yi13 & Yi13 & 1356.83 & Crystalline dedolomite & -9.20 & -6.90 & & & & \\
\hline 62 & Yi13 & Yi13 & 1362.32 & Crystalline dedolomite & -8.90 & -6.50 & & & & \\
\hline 63 & Yi13 & Yi13 & 1362.88 & Crystalline dedolomite & -8.70 & -5.60 & & & & \\
\hline 64 & Yi13 & Yi13 & 1367.88 & Crystalline dedolomite & -8.00 & -6.70 & & & & \\
\hline 65 & Yi13 & Yi13 & 1369.92 & Crystalline dedolomite & -8.00 & -6.50 & & & & \\
\hline 66 & Yi13 & Yi13 & 1372.50 & Crystalline dedolomite & -8.50 & -4.90 & & & & \\
\hline 67 & Yi13 & Yi13 & 1384.57 & Crystalline dedolomite & -8.30 & -6.30 & & & & \\
\hline 68 & Yi13 & Yi13 & 1385.82 & Crystalline dedolomite & -10.00 & -7.30 & & & & \\
\hline 69 & Yi13 & Yi13 & 1386.96 & Crystalline dedolomite & -8.60 & -7.50 & & & & \\
\hline 70 & Yi5 & Yi5 & 2305.96 & Crystalline dedolomite & -9.29 & -6.16 & & & & \\
\hline 71 & Yi5 & Yi5 & 2306.69 & Crystalline dedolomite & -8.08 & -5.32 & & & & \\
\hline \multirow[t]{4}{*}{72} & Yi5 & Yi5 & 2305.71 & Crystalline dedolomite & -8.38 & -6.77 & & & & \\
\hline & & & & $\operatorname{Max}$ & -8.00 & -2.00 & & & & \\
\hline & & & & Min & -10.30 & -7.50 & & & & \\
\hline & & & & Average & -8.84 & -5.86 & & & & \\
\hline
\end{tabular}

are quite different from those of this study. In previous study, the replaced rhombic calcite is composed of polycrystalline calcite mosaics, or the unaltered dolomite core is surrounded by multi-crystalline calcite at the rims or along the rim/core interfaces, whereas, in the present study, the replaced calcite core shows a homogeneous fabric with rims or rim/core interface filled with multi-crystalline dolomite instead of calcite. Previous case studies indicate that the dedolomitization is a process involving dolomite dissolution so that an open pore is formed, which is then cemented by euhedral calcite. The mosaic texture of the crystals in the end product, therefore, indicates an origin through cementation rather than direct replacement (Evamy 1967). Dedolomitization in brecciated dedolomite of this study, however, is a direct replacement process, which changes the rhomb composition but not destroying its original internal crystalline structure.

Previous studies reveal that the calcite solubility is 1.13 times of dolomite (Lu and Zhang 2007). Liu and Wolfgang (2007) also concluded that the primary solubility of calcite is $2.5 \sim 7.5$ times of dolomite solubility according to the karst dynamics experiment. Experiments by Huang et al. (1993) show that calcite is much more readily dissolved than 

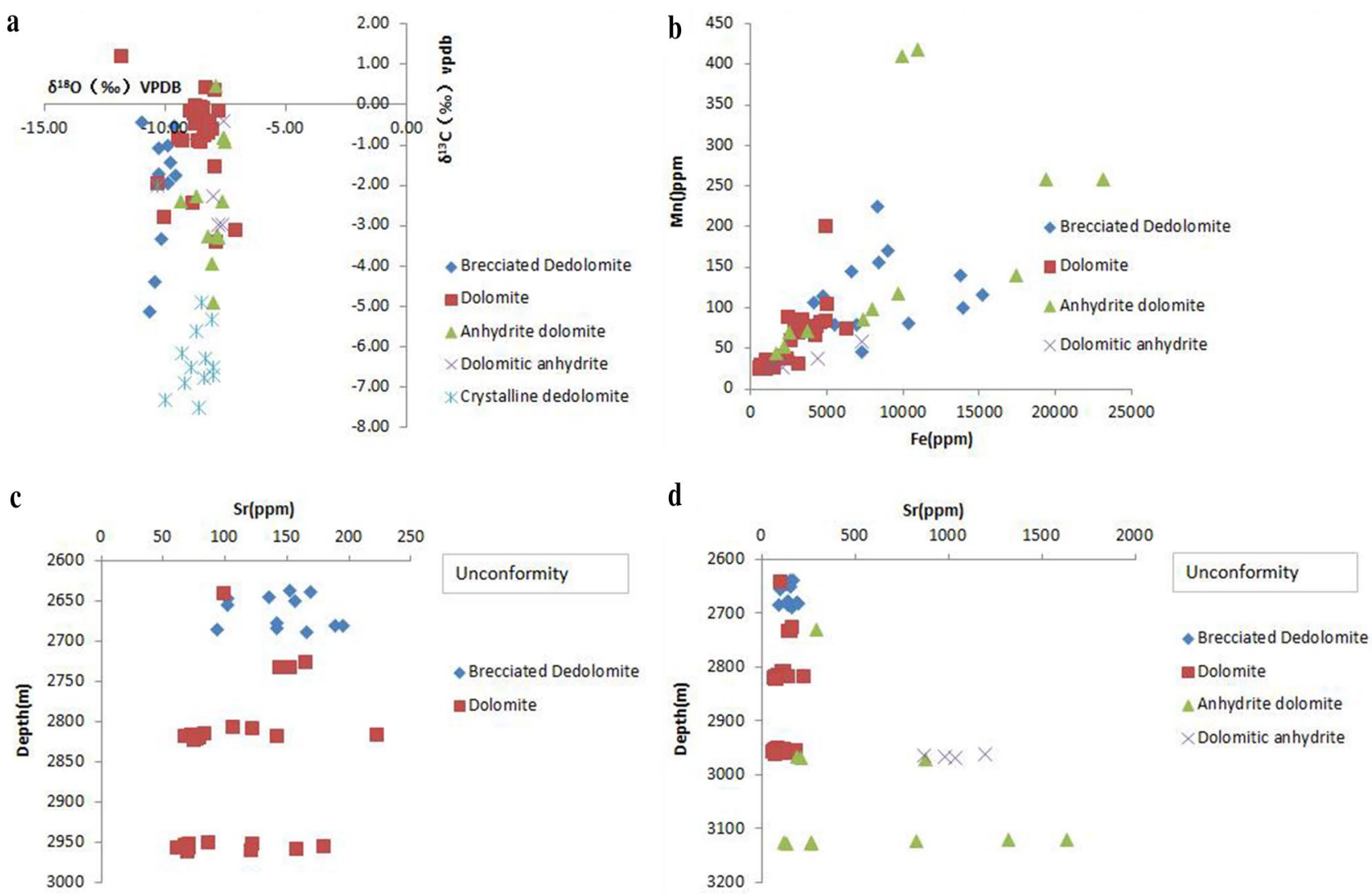

Fig. 9 Geochemistry characteristics of brecciated dedolomite, dolomite, anhydrite dolomite and dolomitic anhydrite of the Majiagou Formation from Yican 1 well in the southeastern Ordos Basin. a Cross-plot of $\delta^{18} \mathrm{O}$ vs. $\delta^{13} \mathrm{C}$ values; b Cross-plot of Fe vs. Mn con-

tent; c Cross-plot of Sr content vs. depth for brecciated dedolomite and dolomite; $\mathbf{d}$ Cross-plot of Sr content vs. depth for brecciated dedolomite, dolomite anhydrite dolomite and dolomitic anhydrite

Table 4 Simulation of different texture dolomite dissolution with or without gypsum under surface environment (Huang et al. 1993; Fang and Hou 2013)

\begin{tabular}{|c|c|c|c|c|c|c|}
\hline \multicolumn{2}{|l|}{ Lithology } & \multirow[t]{2}{*}{ Conidition } & \multirow{2}{*}{$\begin{array}{l}\text { Ca release rate/ } \\
(\mathrm{mg} / \mathrm{L} \cdot \mathrm{h})\end{array}$} & \multirow{2}{*}{$\begin{array}{l}\text { Mg release rate/ } \\
(\mathrm{mg} / \mathrm{L} \cdot \mathrm{h})\end{array}$} & \multirow{2}{*}{$\begin{array}{l}\text { Total } \mathrm{Ca} \text { and } \mathrm{Mg} \\
\text { release content } /(\mathrm{mg} / \mathrm{L})\end{array}$} & \multirow{2}{*}{$\begin{array}{l}\omega(\mathrm{Ca}) / \\
\omega(\mathrm{Mg}) \text { in } \\
\text { solution }\end{array}$} \\
\hline & $\omega(\mathrm{Ca}) / \omega(\mathrm{Mg})$ & & & & & \\
\hline \multirow[t]{2}{*}{ Oolitic dolomite } & 1.98 & Without gypsum & 0.141 & 0.042 & 61.24 & 3.15 \\
\hline & & With gypsum & 0.136 & 0.076 & 64.27 & 1.62 \\
\hline \multirow[t]{2}{*}{ Fine-powder dolomite } & 1.86 & Without gypsum & 0.141 & 0.045 & 58.05 & 2.60 \\
\hline & & With gypsum & 0.139 & 0.075 & 65.72 & 1.62 \\
\hline
\end{tabular}

dolomite under acidic near-surface condition; even though dissolved $\mathrm{CaSO}_{4}$ is added. He simulates a karst dissolution condition under $40^{\circ} \mathrm{C}$ at normal pressure with $0.0596 \mathrm{mg} / \mathrm{L}$ carbonate acid as solvent. The experiment reveals that under the influence of high concentration of calcium ions when dissolved $\mathrm{CaSO}_{4}$ is added to the solvent for dolomite dissolution, the release rates of $\mathrm{Mg}^{2+}$ increases, while the $\mathrm{Ca}^{2+}$ release is restrained (Fang and Hou 2013). The $\omega_{(\mathrm{Ca})} / \omega_{(\mathrm{Mg})}(\omega$ represents the ionic content) in fluid dissolved from oolitic dolomite and fine-powder dolomite is
3.15 and 2.60, respectively without $\mathrm{CaSO}_{4}$ added. When the $\mathrm{CaSO}_{4}$ is added, the two values reduce to 1.62 and 1.62 , respectively (Table 4 ). The experiment results indicate that under the influence of high concentration of calcium ions when dissolved $\mathrm{CaSO}_{4}$ is added to the solvent for dolomite dissolution, the release rates of $\mathrm{Mg}^{2+}$ increases, while the $\mathrm{Ca}^{2+}$ release is restrained. Dedolomitization is therefore an $\mathrm{Mg}^{2+}$-releasing process, which changes the dolomite composition but not its fabric. The zoned dedolomite (Fig. 5b) and dolomite (Fig. 5c) fabric may indicate a probable 


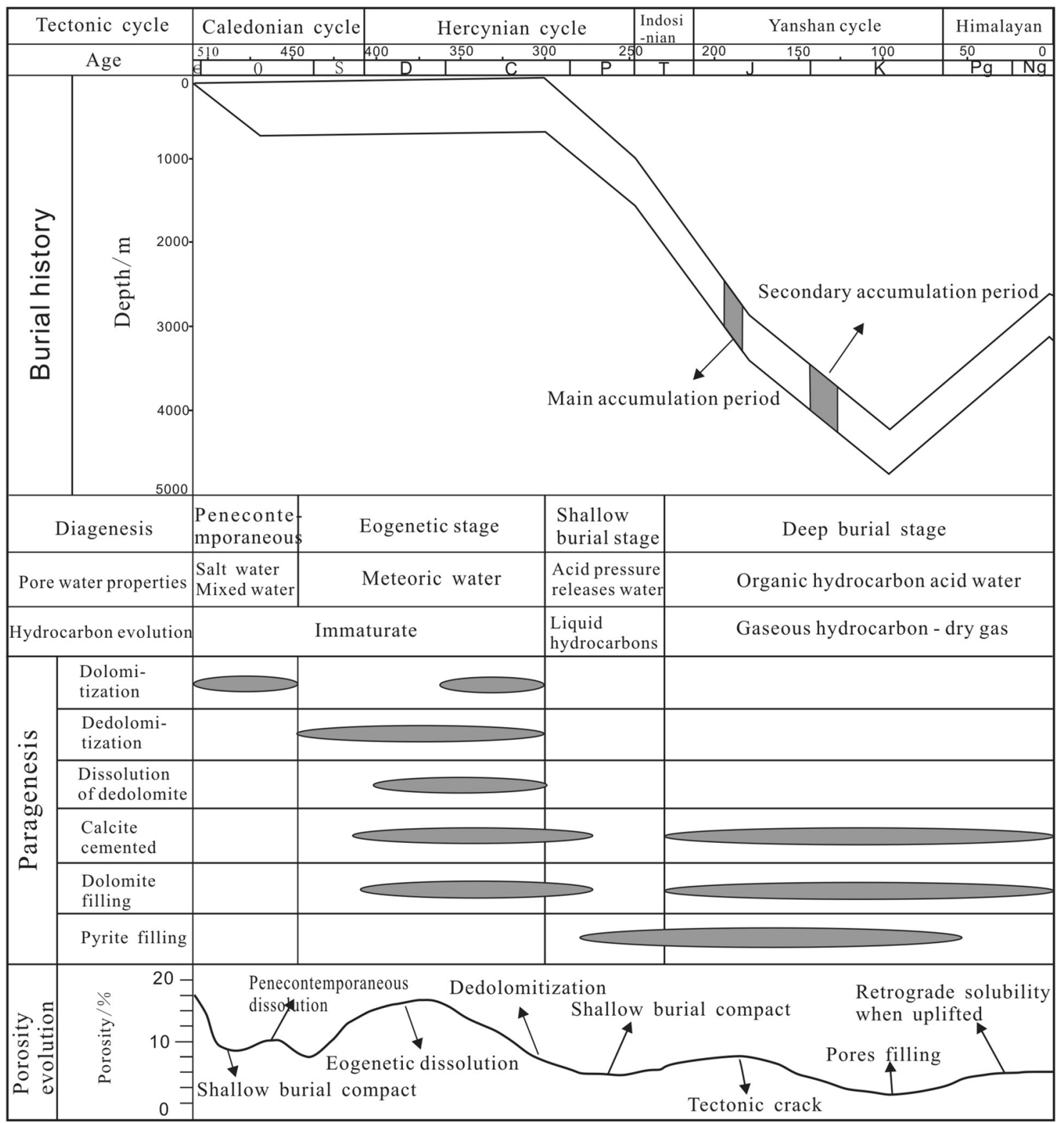

Fig. 10 A paragenetic sequence plot of carbonate in the Ordovician Majiagou Formation in southeastern Ordos basin

dedolomitization process. The ghost of rhombic dedolomite (Fig. 5b) seems like the erosional relic indicating a progressive dedolomitization process. The gradual $\mathrm{Mg}^{2+}$ content decrease from the dark gray cores to the light gray rims (Fig. 5d) confirm the above conclusion.

Because of the higher solubility of calcite than dolomite, it is to be expected that calcite will dissolve in preference to dolomite. Hence the dissolution pores are more developed in dedolomite crystals than in dolomite matrix (Fig. 4j, k). The rhombohedral pores are probably developed through the selective leaching of dedolomite rather than dolomite (Fig. 41). The cementation documented in previous studies seems, therefore, to have concluded a rather complex diagenetic history involving dolomitization, dedolomitization, selective leaching of dedolomite or another phase of dolomitization, and finally calcite cementation (Evamy 1967; Sibley 1980; Nader et al. 2008) (Fig. 10).

It is suggested that the dedolomitization process might be an opposite of dolomitization (Huang et al. 1993). Because protodolomite is thought to be a possible precursor of stoichiometric dolomite (Oomori et al. 1988; Liu et al. 2019), it must be an intermediate product of dedolomitization. Under conditions of a fluid with high $\mathrm{Ca}^{2+} / \mathrm{Mg}^{2+}$ ratio, ordered dolomite firstly transforms to proto-dolomite that is rich in $\mathrm{Ca}^{2+}$, and then into calcite. The dissolution of $\mathrm{Ca}$ sulphate promotes dedolomitization 
by increasing the $\mathrm{Mg}$ ion release and constraining the $\mathrm{Ca}$ ion release. As the dolomite transforms into calcite, the anhydrite-supplied $\mathrm{Ca}$ ion is removed and $\mathrm{Mg}$ ion is released into the solution, thereby leading to a relative high $\mathrm{Mg}^{2+}$ concentration in the vicinity of dedolomite and local re-precipitation of dolomite at the rims or along rim/ core interfaces. The dolomite crystals formed after dedolomitization are authigenic, and therefore, show euhedral to subhedral, differentially oriented fabric. They seem to preferentially occupy dedolomite rim or rim/core interface-probably within sites of abundant fluid inclusions.

\section{Origin of crystalline limestone (Crystalline dedolomite)}

Another common microfabric of dedolomitization is characterized by anhedral calcite crystals, forming crystalline dedolomite with numerous poikilotopic inclusions or aggregates of dolomite. The medium to coarsely crystalline dedolomite with varying amount of dolomite in the Majiagou Formation are similar to those interpreted as the dedolomitization in the Winnipegosis Formation by Fu et al. (2008) and numerous other studies. Various evidences suggest that the crystalline dedolomite in the Majiagou Formation has formed by dedolomitization followed by recrystallization of very fine to fine dedolomite. Dolomite masses within the crystalline dedolomite horizon preserve the relic textures of precursor dolomite and display corrosion fabrics (Fig. 6g, h), strongly suggesting that dolomitization pre-dated the formation of medium to coarsely crystalline dedolomite. The patchy dolomite relics enclosed within the calcite crystals cores are dolomicrite aggregates, indicating that the precursor dolomite has very fine to microcrystalline texture. The crystalline dedolomite is massive and mosaic contact (Fig. 6g, h), indicating that its formation was followed by recrystallization of very finely to finely crystalline dedolomite. The textures of several relic dolomite crystals encased within single to multiple calcite crystals are probably caused by the growth of calcite crystals into the void space away from nucleation sites on the dissolving dolomite crystals (Stoessell et al. 1987; Fu et al. 2008). All the above petrographic observations suggest that the crystalline limestone consisting of massive calcite mosaics in the upper part of the Majiagou Formation has formed by the calcitization of dolomite and is best interpreted as dedolomite. Different from the direct replacement of rhombic dedolomite, the crystalline dedolomite involves a two-step process of dolomite dissolution and calcite precipitation. Because calcite has a higher solubility than dolomite, the calcite must have precipitated from a different solution at a different time (James et al. 1993). As a result of intense dedolomitization and recrystallization, the precursor dolomite is replaced by fine to medium calcite and then recrystallized to a medium to coarse calcite mosaic of newly formed calcite crystals with very low intercrystalline porosity.

Brecciated dedolomite is more common in Yican 1 well, whereas crystalline dedolomites are better developed in Yi 5, Yi 9, Yi 13 and Yi 16 wells. This phenomenon is partly attributed to the fact that the precursor dolomite in Yi 5, Yi 9, Yi 13 and Yi 16 wells are mostly very fine to microcrystalline fabric, which is more soluble than crystalline dolomite because of larger surface area. Furthermore, Yi 5, Yi 9, Yi 13 and Yi 16 wells are tectonically lower than Yican 1 well, where karst water saturated with respect to $\mathrm{CaCO}_{3}$ is more concentrated and facilitate the dissolution of dolomite and the precipitation of calcite.

Because of the relative high solubility of calcite formed by dedolomitization, the dissolution pores are more common in crystalline dedolomite (Fig. 6a, d). If a large section of dolomite of $\mathrm{Ma}_{5}$ has been dedolomitized, continuous dissolution pores may be formed in the longitudinal direction influenced by the heterogeneity of rock structure (Fig. 6e, f). In dolomite and calcite intervals, because of the fast dissolution rate of dedolomite, the ground water flow and dissolution are more and more concentrated in the dedolomite layers. Differential dissolution becomes more and more obvious, and a series of layered karst pores are then often formed in the dedolomite layer in the longitudinal direction (Fig. 6e, f). However, the dissolution pores are always partly or totally cemented by sparry calcite and/or dolomite (Fig. 6e, f).

\section{Paragenesis of dedolomitization}

Dedolomitization occurs in a wide range of diagenetic environments, including the surface environment (Chilingar 1956), early burial environment (De Groot 1967), and deep burial environment (Stoessell et al. 1987). Most case studies conclude that an overwhelming majority of dedolomites form from meteoric waters in the near-surface environment (Ronchi et al. 2004; Nader et al. 2008; Reuning et al. 2009; Schoenherr et al. 2018). In the present study, the dedolomites are only observed in areas where the evaporite deposits are removed or residue-anhydritic breccias are present, suggesting that dedolomitization of the Majiagou Formation is probably related to the dissolution of anhydrite by fresh water, which is supported by the petrographic features and geochemical data of the dedolomite.

The dedolomites are restricted to the uppermost $100 \mathrm{~m}$ below a regional disconformity (Li et al. 2008; Yang et al. 2011), defined by clay minerals and karst dissolution-collapse breccia (Fig. 2d), which indicates its close relationship with erosional unconformities. The dedolomites are often found to be cross-cut by fractures (Fig. 2h). It could be argued that dedolomitization are pre-dated the fractures. 
The $\delta^{13} \mathrm{C}$ values of Ordovician contemporaneous seawater varies between $-2 \%$ - $2 \%$ (Lohmann 1988). The crystalline dedolomite in the Majiagou Formation is characterized by negative $\delta^{13} \mathrm{C}$ values (average of $-5.86 \%$ ), much lower than both that of dolostone (average of $-0.75 \%$ ) and those of brecciated dedolomite (average of $-1.79 \%$ ). The $\delta^{13} \mathrm{C}$ value of dolomite is within the Ordovician contemporaneous seawater, indicating that the dolomite is formed in marine fluid. The strongly negative $\delta^{13} \mathrm{C}$ values of the crystalline dedolomite could be interpreted as resulting from fresh groundwater enriched in soil-derived $\mathrm{CO}_{2}$ (Nader et al. 2008; Liu et al. 2017a) and/or bacterial sulphate reduction (BSR) (Sanz-Rubio et al. 2001; Fu et al. 2008). In combination with the negative $\delta^{18} \mathrm{O}$ value of crystalline dedolomite, the negative $\delta^{13} \mathrm{C}$ values of the crystalline dedolomite cannot be from bacterial sulphate reduction, as SRB will preferentially consume ${ }^{16} \mathrm{O}$ thus often enrich the $\delta^{18} \mathrm{O}$ value. Therefore, the negative $\delta^{13} \mathrm{C}$ values of the crystalline dedolomite are interpreted to be resulted from fresh groundwater involvement. The $\delta^{13} \mathrm{C}$ values of brecciated dedolomite (average of $-1.97 \%$ ) is between that of crystalline dedolomite (average of $-5.86 \%$ ) and dolomite (average of $-0.75 \%$ ), most likely due to varying calcite (dedolomite) content.

The $\delta^{18} \mathrm{O}$ value of Ordovician carbonate varied from $-9.0 \%$ to $-5.4 \%$, average of $-7.6 \%$ o (Shields et al. 2005). The crystalline dedolomite from Yi 5 and Yi 13 wells, and the brecciated dedolomite from Yican 1 well shows relatively negative $\delta^{18} \mathrm{O}$ values (average of $-8.84 \%$ and $-10.14 \%$, respectively) with respect to dolomite (average of $-8.68 \%$ ). The negative $\mathrm{O}$-isotope may be caused by meteoric condition or elevated temperatures, which drive the thermal fractionation of diagenetic carbonate (Hardie 1967; Choquette and James 1990; Liu et al. 2017b). The crystalline dedolomite and brecciated dedolomite shows a wider range of $\delta^{13} \mathrm{C}$ values but a narrower range of $\delta^{18} \mathrm{O}$ values (Fig. 9a), which is a distinctive feature of meteoric diagenesis (Lohmann 1988; Sanz-Rubio et al. 2001; Fu et al. 2008). The general isotope pattern of dedolomites in the Majiagou Formation is similar to that reported by Kenny (1992), Arenas et al. (1999) and Nader et al. (2008), who also interpreted the similar isotope composition in dedolomite to result from an influx of meteoric water.

The High $\mathrm{Sr}$ in the brecciated dolomite (average of $150 \mathrm{ppm}$ ) is because that it formed during dissolution of evaporites, which are naturally high in Sr (Carlson 1983). Stewart (1968) measured $\mathrm{Sr}^{2+}$ contents up to $2000 \mathrm{ppm}$ in marine gypsum and 5000 ppm in anhydrite, which compares to the upper limit of the $\mathrm{Sr}^{2+}$ contents of anhydritic dolostone and dolomitic anhydrite of Yican 1 (maximum of $1499 \mathrm{ppm}$ and $1025 \mathrm{ppm}$, respectively). The value is significantly higher than those in dolomite, average of $107 \mathrm{ppm}$. Because dedolomitization is driven by the sulphate solution as mentioned above, with the dissolution of gypsum and anhydrite, the $\mathrm{Sr}^{2+}$ is released into solution and incorporated into the dedolomites that formed in such fluids with high $\mathrm{Sr}^{2+}$ content. However, it cannot be excluded that the dedolomite or dolomite samples may be polluted by anhydrite resulting in the elevated $\mathrm{Sr}$ content.

The dedolomites often show brownish or reddish color in hand specimen (Fig. 2e). The Fe and Mn content of brecciated dedolomite (average of 8588 ppm and 116 ppm, respectively) is much higher than that of dolomite (average of 2811 ppm and 63 ppm, respectively) (Table 3, Fig. 9b). Due to significant differences of $\mathrm{Fe}$ and $\mathrm{Mn}$ content from continental surface fluid (such as meteoric water) and marine fluid, and because of variable range of partition coefficient and dynamic effect of the two element in carbonate minerals, the carbonate affected by meteoric water commonly has higher Fe and Mn content (Huang et al. 2010). Karstification is the most important geological process of carbonate modification by atmospheric water, resulting in relatively high $\mathrm{Fe}$ and $\mathrm{Mn}$ content in the carbonate formed near the unconformity surface. Therefore, the content of Fe and $\mathrm{Mn}$ in carbonate becomes one of the methods to identify the paleo-karstification and determine the effective depth of atmospheric water during the karst process. During uplift, subaerial exposure and karstification through the circulation of meteoric water, $\mathrm{Fe}^{2+}$ is incorporated into the dedolomite and oxidized in the open system to form hematite occurring as thin coating on the crystals. Many dedolomites are, therefore, heavily stained with iron oxides and hydroxides and exhibit brownish or reddish rock colors. All of the above features reveal that the dedolomites formed under the influence of relatively fresh water during subaerial exposure in a surface environment.

\section{Impact on reservoir quality}

It is most commonly suggested that the dedolomitization process will reduce the reservoir porosity ( $\mathrm{Li} \mathrm{1998;} \mathrm{Hu} \mathrm{et} \mathrm{al.}$ 2008; Shi et al. 2010; Tone et al. 2018). However, numerous studies have also shown an enhancement of reservoir quality by dedolomitization (e.g., Schmidt 1965; Evamy 1967; Braun and Friedman 1970; Frank 1981; Qin and Yang 1997). Theoretically, $12.9 \%$ void volume will be produced by the dolomitization reaction involving $1 \mathrm{~mol}$ of dolomite $(64.4$ $\mathrm{cm}^{3}$ ), which is $12.9 \%$ less than $2 \mathrm{~mol}$ of calcite by volume $\left(73.9 \mathrm{~cm}^{3}\right)((73.9-64.4) / 73.9 * 100 \%)$ (Ayora et al. 1998; Hallenberger et al. 2018). The reservoir quality of dolostones is therefore significantly higher than that of limestones, such as in the Feixianguan Formation in the Sichuan Basin (Jiang et al. 2018) and the Ordovician carbonate in the Tazhong area of the Tarim Basin (Jia et al. 2016). Similarly, the solid volume will increase by $14.7 \%$ during the replacement of dolomite by calcite ((73.9-64.4)/64.4*100\%). Therefore, in brecciated dedolomite of Yican 1 well, the micropores are 
well developed in dolomite matrix, but rarely observed in dedolomite crystals (Fig. 5b, c) due to the porosity shrinkage effect. The overall reservoir quality is, therefore, reduced in the dedolomitization process.

Whereas, because of higher solubility of calcite than dolomite, the dissolution vugs and pores are expected to be more developed in dedolomite (Fig. 4j, k), even form rhombohedral pores (Fig. 41). The pores from dedolomite dissolution are commonly isolated and less abundant, which contributes little to the overall porosity of the horizon. The pore space of Yican 1 well mainly originates from anhydrite dissolution pores and fractures, which mainly occurs in the uppermost $10 \mathrm{~m}$ of the Majiagou Formation. The crystalline dedolomite, however, are formed by dissolution/precipitation and recrystallization of precursor dolomicrite. As a result, the remaining pores may be occluded as long as excess calcium is supplied into a closed diagenetic system to enable dedolomitization, which will reduce the reservoir porosity. The dedolomitization will change both the composition and fabric of the precursor dolomite. The composition is changed from dolomite into calcite, whereas the fabric is changed from micrite crystals to medium-coarse crystals, even up to very coarse crystals. The calcite crystals are massive, anhedral and for a tight mosaic to make the rock low porosity. Yi 16 well, where the crystalline dedolomite is present shows low porosity of $1.04 \%$ (Table 2). Although the pores form by dissolution are developed in the crystalline dedolomite, the pores are always isolated in distribution (Figs. 6a, d), which is poorly connected for lack of fracture. Most of pores are cemented with calcite and/or dolomite, which occlude the pore space to reduce the reservoir porosity (Figs. 6e, f). Dedolomitization, therefore, can be a spatially very pervasive process, which has reduced reservoir quality, not only on a local but also on a regional scale.

\section{Major controlling factors on the dedolomitization}

\section{(1) $\mathrm{Ca}^{2+} / \mathrm{Mg}^{2+}$ ratio in the diagenetic fluid}

Experiments have shown that the $\mathrm{Ca}^{2+} / \mathrm{Mg}^{2+}$ ratio and fluid rate are the major factors that control dedolomitization (De Groot 1967). Dedolomitization in the study area occurs during subaerial exposure related to a regional unconformity. Based on the above discussion, the dissolution of $\mathrm{Ca}$ sulphate will increase the $\mathrm{Mg}^{2+}$ release rate, while reducing the $\mathrm{Ca}^{2+}$ release rate. In an open system, the produced $\mathrm{Mg}^{2+}$ will be removed, which is favorable for the reaction to proceed. The dedolomitization reactions will be faster with higher $\mathrm{Ca}^{2+} / \mathrm{Mg}^{2+}$ values.

A continuous profile across four wells in the southeast of the Ordos Basin is shown by the vertical distribution of well log correlations in Fig. 11. The top of the Taiyuan Formation is positioned at the same depth to compare the pre-Carboniferous paleo-topography. When the overlying Taiyuan and Benxi Formation is thin, the pre-Carboniferous paleo-topography is relatively high (e.g., Yican 1 and Yi 8 wells). When the Taiyuan and Benxi Formation is thick, the pre-Carboniferous paleo-topography is relative low (Yi 9 and Yi 16 well) (Fig. 11). An overall trend

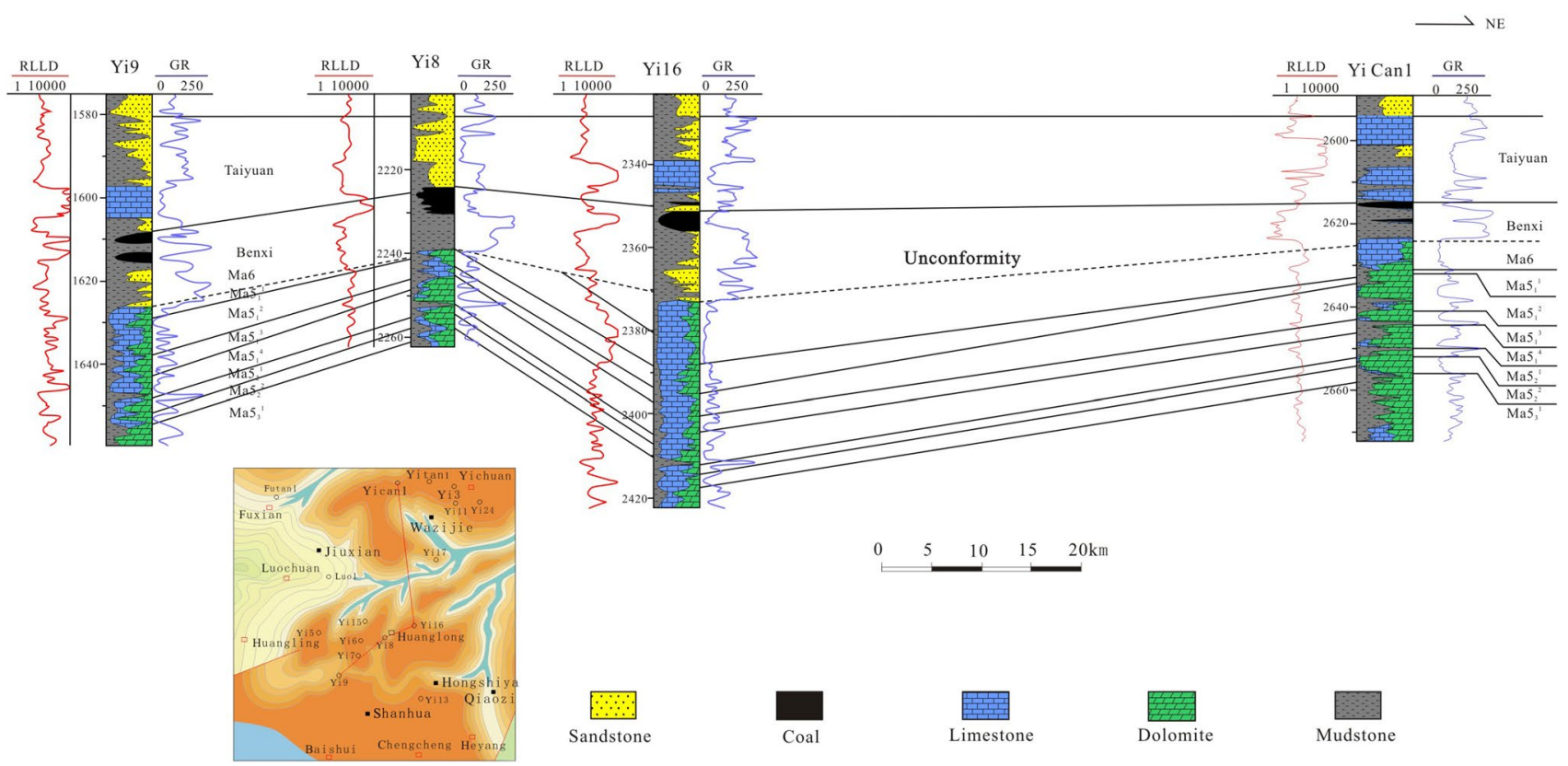

Fig. 11 Profile across four wells with vertical distribution of the well $\log$ correlations indicating an increase of limestone proportion from the topographically higher towards lower parts of the basin ( Modi- fied from Liu et al. 2011). The limestone are all crystalline dedolomites in member $\mathrm{Ma}_{5}$. Only the member $\mathrm{Ma}_{6}$ is composed of primary limestone 
of increasing dedolomite proportion of $\mathrm{Ma}_{5}$ member is observed from the topographically higher towards lower parts of the basin (Liu et al. 2011). The lower part of the basin is the converging location of the karst fluid, where bears a higher $\mathrm{Ca}^{2+} / \mathrm{Mg}^{2+}$ ratio and is oversaturated with respect to calcite. The rock-fluid reaction lasts for a considerable duration when $\mathrm{Ca}^{2+} / \mathrm{Mg}^{2+}$ are high promoting the replacement of dolomite by calcite and subsequently recrystallization. It's therefore suggested to implement drilling in tectonic highland and avoid low locations in paleo-topography.

(2) Dolomite stoichiometry

Dedolomitization often begins within the core and progresses outwards toward the crystal edges (Fig. 5), because the cloudy cores of dolomite has stoichiometry about 53\%-56 M\% $\mathrm{CaCO}_{3}$, which is believed to be less stable. While as the clear rims are nearly to be stoichiometric with $50 \% \sim 53 \mathrm{M} \% \mathrm{CaCO}_{3}$, which are less prone to alteration. Therefore, the dedolomitization is partially controlled by their stoichiometry.

(3) Fracture development degree

Numerous studies have demonstrated that fractures acted as the preferred flow pathways for dedolomitizing fluids (Zeeh et al. 2000; Reuning et al. 2009; Schoenherr et al. 2018). Dedolomitization is much more developed in fractures or adjacent region in the southeastern Ordos basin. Tectonic in Caledonian movement is the root cause for the formation of a massive fracture network within the dolostone unit, which provides more paleo-conduits for the dedolomitizing fluid and causes the pervasive and large scale dedolomitization.

\section{Conclusions}

(1) Two types of dedolomites were recognized in the upper $100 \mathrm{~m}$ of the Majiagou Formation, namely brecciated dedolomite and crystalline dedolomite.

(2) The brecciated dedolomite is mainly composed of dark gray matrix and light gray clasts, in which calcitized dolomite crystals are scattered in micritic dolostone matrix or form crystal aggregates as the clasts of breccia. Four types of calcitized dolomite are identified in brecciated dedolomite, including the dolomite crystals distributed at the rim, or along the rim/core interface, or scattered in the calcitized dolomite crystal, as well as the partial or complete dissolution of the crystal. The brecciated dedolomite is formed by $\mathrm{Mg}^{2+}$ release process, instead of a dolomite dissolution/ calcite precipitation process.

(3) Crystalline dedolomite is characterized by xenotopic, medium to coarsely, crystalline calcite mosaics with variable amount of dolomite impurities in crystal cores, which are considered to be formed by dolomite dissolution and calcite precipitation followed by recrystallization. As a result of intense replacement and recrystallization, the precursor dolomite is replaced by finely to medium calcite and then recrystallized to medium to coarsely calcite mosaic of newly formed calcite crystals with very low intercrystalline porosity.

(4) The dedolomites often occur with clay minerals and karst dissolution-collapse breccia, and are fractured with brownish or reddish color in hand specimens, strongly suggesting their close relationship with the erosional unconformities.

(5) Geochemical evidence further supports that the dedolomites formed in fluids of meteoric origin when uplifted in the Caledonian orogeny in lower Paleozoic, which are depleted in $\delta^{18} \mathrm{O}$ and $\delta^{13} \mathrm{C}$ values, and enriched in $\mathrm{Fe}$ and $\mathrm{Mn}$. Because the dedolomite mainly occurs in anhydrite-dolomite intervals, we suggest that the dedolomitization is driven by evaporite dissolution when subject to exposure and erosion by meteoric water. The high $\mathrm{Sr}$ contents likely derive from the anhydrite dissolution, which has a high $\mathrm{Sr}$ content.

(6) The brecciated dedolomites are common in Yican 1 well, whereas the crystalline dedolomite mainly occurs in Yi 5, Yi 9, Yi 13 and Yi 16 wells, which is attributed to the precursor texture and tectonic locations. The precursor dolomites in Yi 5, Yi 9, Yi 13 and Yi 16 wells are mostly very finely to microcrystalline fabric, which is more soluble than crystalline dolomite because of larger surface area. The pre-Carboniferous paleo-topography of Yi 5, Yi 9, Yi 13 and Yi 16 wells is relative low, where karst water with saturated $\mathrm{CaCO}_{3}$ is more concentrated and facilitates the dissolution of dolomite and the precipitation of calcite. It's therefore suggested to implement drilling in tectonic highland and avoid low location in paleo-topography.

Acknowledgements This work is supported by the National Natural Science Foundation of China (No. 41802173) and China Geological Survey (Nos. DD20160175; DD20190106; DD20190708; DD20190090; DD20190606). The work is part of the outcome of the first author's PhD thesis (Peking University), under the guidance of Prof. Yongsheng Ma (Sinopec Co., Ltd.) and Prof. Bo Liu (Peking University), who are greatly acknowledged. We are grateful to Prof. Sijing Huang for his constructive comments and suggestions that have significantly improved the manuscript. We would like to thank Huan Wang from China University of Petroleum for kindly operating the SEM and EDS analysis. We heartily thank all those involved in the field study.

Author contributions Conceptualization, methodology, writing-original draft, LL; investigation, writing-review and editing, CW; resources, funding acquisition, $\mathrm{ZD}$; validation, visualization, project administration, KH. All authors have read and agreed to the published version of the manuscript.

Funding This work was funded by the National Natural Science Foundation of China (No. 41802173) and China Geological Survey 
(Nos.DD20160175; DD20190106; DD20190708; DD20190090; DD20190606).

Data availability The data presented in this study are available on request from the corresponding author.

\section{Declarations}

Conflict of interest The authors declare no conflict of interest.

Open Access This article is licensed under a Creative Commons Attribution 4.0 International License, which permits use, sharing, adaptation, distribution and reproduction in any medium or format, as long as you give appropriate credit to the original author(s) and the source, provide a link to the Creative Commons licence, and indicate if changes were made. The images or other third party material in this article are included in the article's Creative Commons licence, unless indicated otherwise in a credit line to the material. If material is not included in the article's Creative Commons licence and your intended use is not permitted by statutory regulation or exceeds the permitted use, you will need to obtain permission directly from the copyright holder. To view a copy of this licence, visit http://creativecommons.org/licenses/by/4.0/.

\section{References}

Al-Hashimi WS, Hemingway JE (1973) Recent dedolomitization and the origin of the rusty crusts of Northumberland. J Sediment Petrol 43:82-91

Arenas C, Alonso Zarza AM, Pardo G (1999) Dedolomitization and other early diagenetic processes in Miocene lacustrine deposits, Ebro Basin (Spain). Sediment Geol 125:23-45

Ayora C, Taberner C, Saaltink MW, Carrera J (1998) The genesis of dedolomites: a discussion based on reactive transport modeling. J Hydrol 209:346-365

Bao HP, Yang CY, Huang JS (2004) "Evaporation drying" and "reinfluxing and redissolving"-a new hypothesis concerning formation of the Ordovician evaporites in eastern Ordos Basin. J Palaeogeogr 6:279-288 (in Chinese with English abstract)

Bao HP, Yang F, Cai ZH, Wang QP, Wu CY (2017) Origin and reservoir characteristics of Ordovician dolostones in the Ordos Basin. Nat Gas Ind 4:106-119 (in Chinese with English abstract)

Braun M, Friedman GM (1970) Dedolomitization fabric in peels: a possible clue to unconformity surfaces. J Sediment Petrol 40:417-419

Budai JM, Lohmann KC, Owen RM (1984) Burial dedolomite in the Mississippian Madison limestone, Wyoming and Utah thrust belt. J Sediment Petrol 54:276-288

Canaveras JC, Sanches-Moral S, Calvo JP, Hoyos M, Ordones S (1996) Dedolomites associated with kastification: an example of early dedolomitization in lacustrine sequences from the tertiary Madrid Basin, Central Spain. Carbonates Evaporites 11:85-103

Carlson EH (1983) The occurrence of Mississippi valley-type mineralization in northwestern Ohio. In: Kisvarsanyi G, Grant SK, Pratt WP, Koenig JW (eds) International conference on Mississippi valley type lead-zinc deposits, proceedings. University of Missouri, Rolla, pp 424-435

Chilingar GV (1956) Dedolomitization a review: American association of petroleum geologists. Bulletin 40:762-764

Choquette PW, James NP (1990) Limestones - burial diagenetic environments. In: Mcilreath IA, Morrow DW (eds) Diagenesis. Geoscience Canada Reprint Series, pp 75-112
Clark DN (1980) The diagenesis of Zechstein carbonate sediments: the Zechstein Basin with emphasis on carbonate sequences. Contrib Sedimentol 9:167-203

De Groot K (1967) Experimental dedolomitization. J Sediment Petrol 37:1216-1220

Escorcia LC, Gomez-rivas E, Daniele L, Corbella M (2013) Dedolomitization and reservoir quality: insights from reactive transport modeling. Geofluids 13:221-231

Evamy BD (1967) Dedolomitization and the development of rhombohedral pores in limestones. J Sediment Petrol 37:1204-1215

Fang SX, Hou FH (2013) Carbonate diagenesis[M]. Geological Publishing House, Beijing, p 148 (in Chinese)

Faust GT (1949) Dedolomitization and its relation to a possible derivation of a magnesium-rich hydrothermal solution. Am Mineral 34:780-823

Feng ZZ, Bao ZD, Kang QF (1999) Palaeotectonics of Ordovician in Ordos. J Palaeogeogr 1:83-94 (in Chinese with English abstract)

Flügel E (2010) Microfacies of carbonate rocks: analysis, interpretation and application, 2nd edn. Springer, Berlin, pp 332-334

Frank JR (1981) Dedolomitization in the Taum Sauk limestone (Upper Cambrian) Southeast Missouri. J Sediment Petrol 51:7-18

Fu JH, Zhen CB (2001) Evolution between North China sea and Qilian sea of the Ordovician and the characteristics of lithofacies palaeogeography in Ordos Basin. J Palaeogeogr 3:25-34 (in Chinese with English abstract)

Fu QL, Qing HR, Bergman KM (2008) Dedolomitization and calcite cementation in the middle Devonian Winnipegosis formation in Central Saskatchewan, Canada. Sedimentology 55:1623-1642

Hallenberger M, Reuning L, Schoenherr J (2018) Dedolomitization potential of fluids from gypsum-to-anhydrite conversion: mass balance constraints from the Late Permian Zechstein-2-carbonates in NW Germany. Geofluids 2018:1-9

Hardie LA (1967) The gypsum-anhydrite equilibrium at one atmosphere pressure. Am Mineral 52:171

He ZX (2003) The evolution and petroleum of Ordos Basin. Petroleum Industry Press, Beijing (in Chinese with English abstract)

Hu ZG, Zheng RC, Wen HG, Cai JL, Chen SC, Hu JZ, Li GL (2008) Dolostone genesis of Huanglong formation of Carboniferous in Linshui of eastern Sichuan northern Chongqing area. Acta Petrologica Sinica 24:1339-1378 (in Chinese with English abstract)

Huang SJ (2010) Carbonate diagenesis[M]. Geological Publishing House, $\mathrm{p} 159$

Huang SJ, Yang JJ, Zhang WZ, Huang MY, Liu GX (1993) Experimental approach to dedolomitization. J Chendu Coll Geol 20:81-86 (in Chinese with English abstract)

Huang SJ, Pan XQ, Lyu J, Qi SC, Huang KK, Lan YF, Wang CM (2013) Hydrothermal dolomitization and subsequent retrograde dissolution in Qixia formation, West Sichuan: a case study of incomplete and halfway-back dolomitization. J Chendu Coll Geol 40:288-300 (in Chinese with English abstract)

James NP, Bone Y, Kyser TK (1993) Shallow burial dolomitization and dedolomitization of mid-Cenozoic, coolwater, calcitic, deep-shelf limestones, southern Australia. J Sediment Petrol 63:528-538

Jia LQ, Cai CF, Jiang L, Zhang K, Li HX, Zhang W (2016) Petrological and geochemical constraints on diagenesis and deep burial dissolution of the Ordovician carbonate reservoirs in the Tazhong area Tarim Basin, NW China. Mar Pet Geol 78:271-290

Jiang L, Worden RH, Cai CF, Shen AJ, He XY, Pan LY (2018) Contrasting diagenetic evolution patterns of platform margin limestones and dolostones in the Lower Triassic Feixianguan formation Sichuan Basin, China. Mar Pet Geol 92:332-351

Kendall AC (1979) Continental and supratidal (sabkha) evaporites. In: Walker RG (ed) Facies models. Reprint Set, Canada, pp 145-158 
Kenny R (1992) Origin of disconformity dedolomite in the Martin formation (Late Devonian, northern Arizona). Sediment Geol 78:137-146

Khalaf FI, Abdal MS (1993) Dedolomitization of dolocrete deposits in Kuwait Arabian Gulf. Geol Rundsch 82:741-749

Li C (1998) Carbonate rock diagenesis of Upper Carboniferous in the East of Sichuan Province. J Univ Pet 22:19-22 (in Chinese with English abstract)

Li J, Zhang WZ, Luo X, Hu GY (2008) Paleokarst reservoirs and gas accumulation in the Jingbian field, Ordos Basin. Mar Pet Geol 25:401-415

Lindholm RC, Finkelman RB (1972) Calcite staining: semiquantitative determination of ferrous iron. J Sediment Petrol 42:239-245

Liu ZH, Wolfgang D (2007) Karst dynamics and environment[M]. Geological Publishing House, Beijing, pp 110-144 (in Chinese)

Liu BX, Wang HW, Ma ZR, Li L, Li Y (2011) Secondary limestone action on $\mathrm{Ma}_{5}$ member dolomites in Yichuan-Huanglong region of Southeastern Ordos Basin. Nat Gas Geosci 22:789-795

Liu LH, Du XD, Xu SL, Wen HG (2017a) Characteristics and formation of the Cambrian Dolomite in Middle-South Sichuan Basin, China. J Jilin Univ (earth Science Edition) 47:775-784 (in Chinese with English abstract)

Liu LH, Ma YS, Liu B, Wang CL (2017b) Hydrothermal dissolution of Ordovician carbonates rocks and its dissolution mechanism in Tarim Basin, China. Carbonates Evaporites 32:525-537

Liu D, Yu N, Papineau D, Fan QG, Wang HM, Qiu X, She ZB, Luo GM (2019) The catalytic role of planktonic aerobic heterotrophic bacteria in protodolomite formation: results from Lake Jibuhulangtu Nuur, Inner Mongolia, China. Geochimica et Cosmochimica Act 263: 31-49

Lohmann KC (1988) Geochemical patterns of meteoric diagenetic systems and their application to studies of paleokast. In: James NP, Choquette PW (eds) Paleokarst. p 58-80

Lu YR, Zhang FE (2007) Study on the development mechanism and engineering effect of carbonate rock karst and the compound karst of sulfate and carbonate[M]. Higher Education Press, Beijing, pp 44-157 (in Chinese)

Lyu J, Huang SJ, Huang KK, Lan YF (2013) Dedolomitization in saddle dolomites of Middle Permian Qixia formation, Western Sichuan Basin, China. J Cent South Univ (science and Technology) 44:1988-1995

Nader FH, Swennen R, Keppens E (2008) Calcitization/dedolomitization of Jurassic dolostones (Lebanon): results from petrographic and sequential geochemical analyses. Sedimentology 55:1467-1485

Oomori T, Kanesshima K, Kitano Y (1988) Solubilities of calcite, aragonite and protodolomite in supratidal brines of Minamidaitojima Island Okinawa, Japan. Mar Chem 25:57-74

Qin JX, Yang ZS (1997) Dedolomitization of carbonate rocks in Ordos and its relation to reservoir property. Oil Gas Geol 18:319-325 (in Chinese with English abstract)

Rains MA, Dewers TA (1997) Dedolomitization as a driving mechanism for karst generation in Permian Blaine formation Southwestern Oklahoma, USA. Carbonates Evaporites 2:24-31

Rameil N (2008) Early diagenetic dolomitization and dedolomitization of late Jurassic and earliest Cretaceous platform carbonates: a case study from the Jura Mountains (NW Switzerland, E France). Sediment Geol 212:70-85

Reuning L, Schoenherr J, Heimann A, Urai J, Littke R, Kukla PA, Rawahi Z (2009) Constraints on the diagenesis, stratigraphy and internal dynamics of the surface-piercing saltdomes in the Ghaba Salt Basin (Oman): a comparison to the Ara Group in the South Oman Salt Basin. GeoArabia 14:83-120

Ronchi P, Jadoul F, Savino R (2004) Quaternary dedolomitization along fracture systems in a Late Triassic dolomitized platform (western southern Alps, Italy). Carbonates Evaporites 19:51-66
Sallam ES, Afife MM, Fares M, van Loon AJ, Ruban DA (2019a) Sedimentary facies and diagenesis of the Lower Miocene Rudeis formation (southwestern offshore margin of the Gulf of Suez, Egypt) and implications for its reservoir quality. Mar Geol 413:48-70

Sallam ES, Afife MM, Fares M, van Loon AJ, Ruban DA (2019b) Depositional cycles of the Lower Miocene Rudeis formation (southwestern offshore margin of the Gulf of Suez, Egypt): implications for reservoir evaluation. Mar Geol 415:105964

Sanz-Rubio E, Sanchez-Moral S, Canaveras JC, Calvo JP, Rouchy JM (2001) Calcitization of $\mathrm{Mg}$-Ca carbonate and $\mathrm{Ca}$ sulphate deposits in a continental tertiary basin (Calatayud Basin, NE Spain). Sediment Geol 140:123-142

Schmidt V (1965) Facies, diagenesis, and related reservior properties in the Gigas Beds Upper Jurassic, northwestern German. In: Pray LC, Murray RC (eds) Dolomitization and limestone diageneses. SEPM Special Publication, London, pp 124-168

Schoenherr J, Reuning L, Hallenberger M, Lüders V, Lemmens L, Biehl BC, Lewin A, Leupold M, Wimmers K, Strohmenger CJ (2018) Dedolomitization: review and case study of uncommon mesogenetic formation conditions. Earth-Sci Rev 185:780-805

Shearman DJ, Khouri J, Taha S (1961) On the replacement of dolomite by calcite in some Mesozoic limestone from the French Jura. Proc Geol Assoc 72:1-12

Shi DS, Jiang XF, Wang QZ (2010) Dedolomitization of lacustrine carbonate rock and influence on reservoir property, Sha IV member of Dongying Sag. Pet Geol Recover Effic 17:16-19 (in Chinese with English abstract)

Shields GA, Garden GAF, Veizer J, Meidla T, Rong JY, Rong YL (2003) Sr, C and O isotope geochemistry of Ordovician brachiopods: a major isotope event around the middle-late Ordovician transition. Geochimica et Cosmochimica Acta 6: 2005-2025

Sibley DF (1980) Climatic control of dolomitization, Seroe Domi formation (Pliocene), Bonaire, N.A. In: Zenger DH, Dunham $\mathrm{JB}$, Ethington RL (eds) Concepts and models of dolomitization. SEPM Special publication, pp 247-258

Stewart FH (1968) Geochemistry of marine evaporite deposits. Geol Soc Am Spec Pap 88:539-540

Stoessell RK, Klimentidis RE, Prezbindowski DR (1987) Dedolomitization in $\mathrm{Na}-\mathrm{CaCl}$ brines from 100 to $200{ }^{\circ} \mathrm{C}$ at 300 bars. Geochimica et Cosmoschimica Acta 51: 847-855

Swennen R, Viaene W, Cornelissen C (1990) Petrography and geochemistry of the Belle Roche breccia (lower Visean, Belgium): evidence for brecciation by evaporite dissolution. Sedimentology 37:859-878

Tian Y, Du ZL, Liu BX, Du XD, Chen Y (2017) Characteristics of Ordovician weathering crust reservoir in Yichuan-Huanglong Area Southeastern Ordos Basin. J Jilin Univ (earth Science Edition) 47:1620-1630

Tone S, Lars S, Snorre O (2018) Upper Permian carbonates at the northern edge of the Zechstein basin Utsira high, Norwegian North Sea. Mar Pet Geol 89:635-652

Von Morlot A (1847) Über Dolomit und seine künstliche Darstellung aus Kalkstein. Haidinger; aus den Naturwissenschaftlichen Abhandlungen, Band 1. Wien, Braumüller pp. 305.

Warren JK (2016) Salt dissolution and pointers to vanished evaporites: Karst, breccia, nodules and cement. Evaporites. Springer, pp 639-761

Wei GQ, Zhu QY, Yang W, Zhang GL, Mo W (2019) Cambrian faults and their control on the sedimentation and reservoirs in the Ordos Basin, NW China. Pet Explor Dev 46:883-895

Wood GW, Armstrong AK (1975) Diagenesis and stratigraphy of the Lisburne group limestones of the Sadlerochit mountains and adjacent areas, northeastern Alaska. US Geol Surv Prof Pap 857:47

Yang YT, Li W, Ma L (2005) Tectonic and stratigraphic controls of hydrocarbon systems in the Ordos Basin: a multicycle cratonic basin in central China. Am Assoc Pet Geol Bull 89:255-269 
Yang H, Fu JH, Wei XS, Ren JF (2011) Natural gas exploration domains in Ordovician marine carbonates, Ordos Basin. Acta Petrolei Sinica 32:733-740 (in Chinese with English abstract)

Zeeh S, Becker F, Heggemann H (2000) Dedolomitization by meteoric fluids: the Korbach fissure of the Hessian Zechstein basin, Germany. J Geochem Explor 69:173-176
Publisher's Note Springer Nature remains neutral with regard to jurisdictional claims in published maps and institutional affiliations. 